\title{
التمايز و إشكال التفاعل مع واقع الجفاء في الفكر المقاصدي
}

إسماعيل الحسني

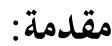

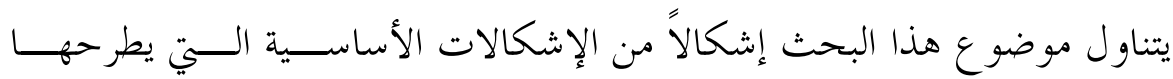

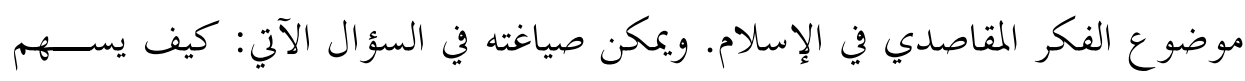
الفكر المقاصدي في التفاعل مع الواقع؟ لقد حاولت الدراســـات الأصــــلية القديمـــة

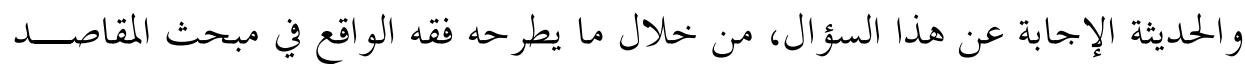

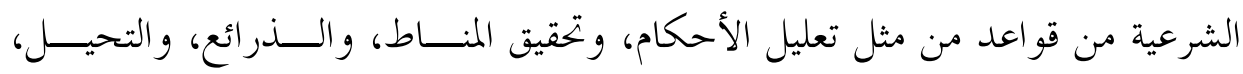
والاستحسان و الاستصلاح.

لقد سبق لي من خلال كتابي الأول، نظرية المقاصد عند الإمام محمد الطاهر بــن

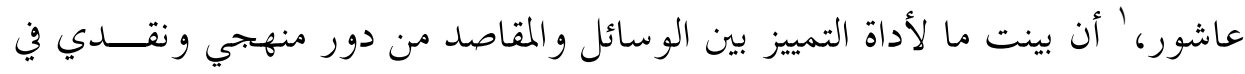

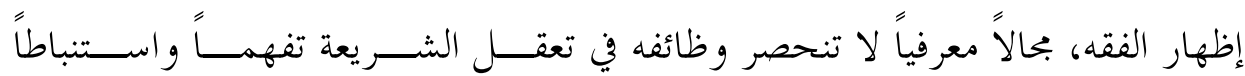
فحسب، وإنما تشمل وظائفه وأهدافه الحرص الدؤوب على تطبيق الأحكام الشرعية، و التبصر الو اعي .بمآلات تنــزيلها. والحق أن هذا التبصر الواعي بالمـــآلات، وذلـــك

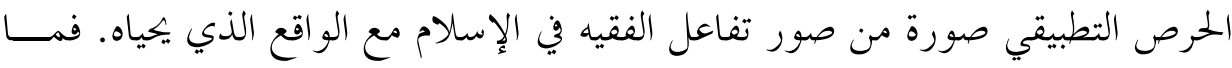

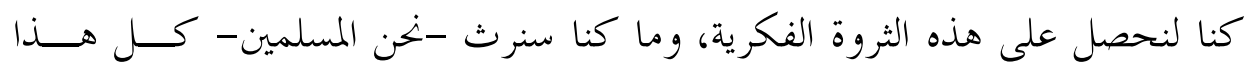
التراث الفقهي، لو سادت بين فقهائنا العظام نزعات الإنكار المطلق لواقعهم، ونزعات الاستسالوم له.

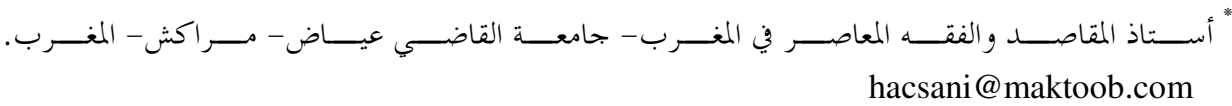

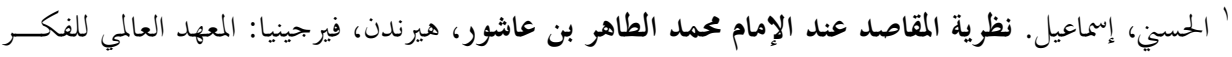

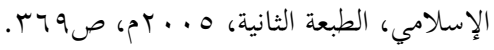


إن الإنكار المطلق و الاستسلام التام نزعتان تفاعليتان مع الواقع، لكنهما نزعتــان

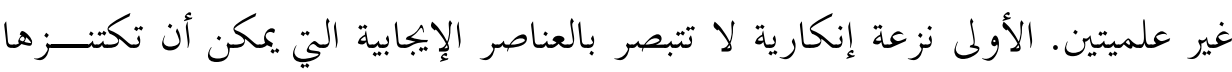

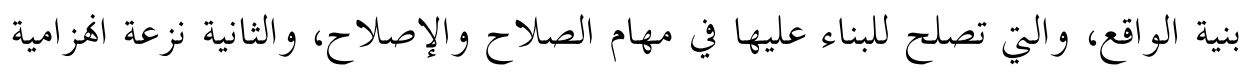
استسلامية لا تولي شطر إر ادها إلى تقويم ما يستحق التقويم، و الإبقاء على ما يســتحق

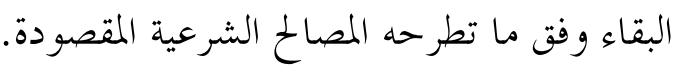

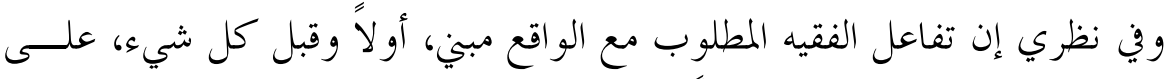

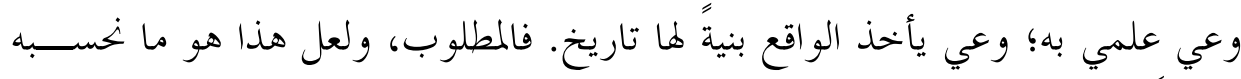

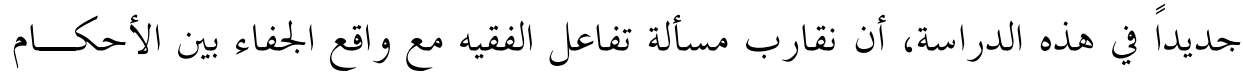

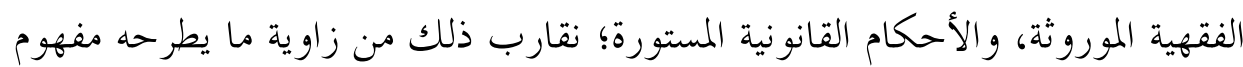

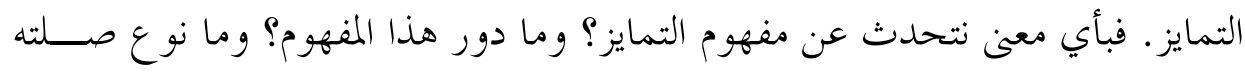
بإشكال التفاعل مع واقع الجفاء في الفكر المقاصدي؟ وقبل هذئ هذا وذاك ماذا أعني بالفكر المقاصدي؟

\section{أولاً: الفكر المقاصدي ومفهوم التمايز}

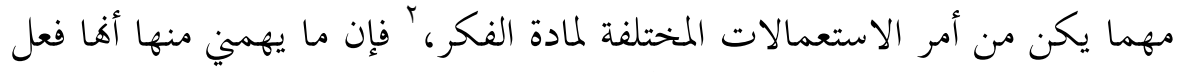

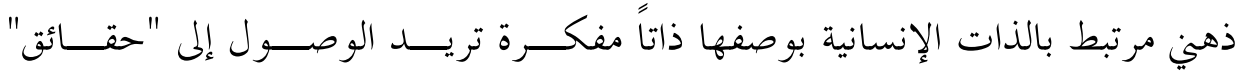

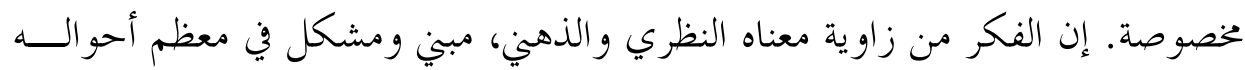

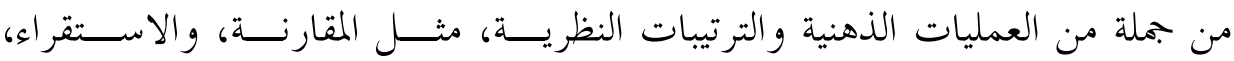
و الاستقصاء، و الفهم، و التساؤل، و الاعتراض، وتحليل الأمر الواحد إلى أجزاء متعددة،

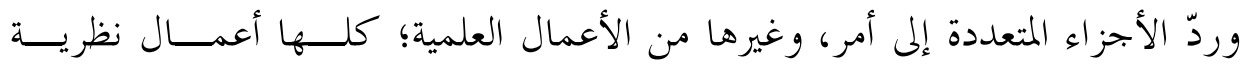

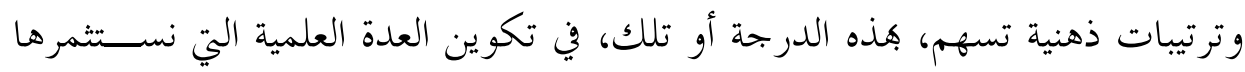
ونوظفها في التوصل إلى المقاصد الشرعية، ومن تمح في بناء فكرنا المقاصدي.

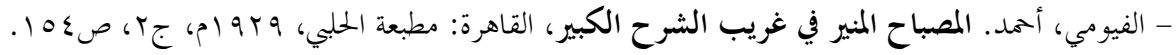

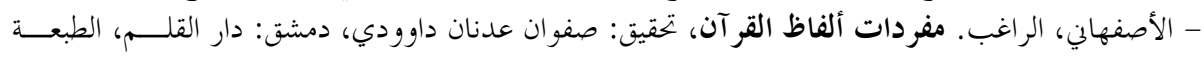




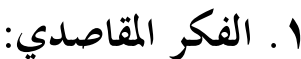

إن وصفي للفكر بأنه مقاصدي مستمد من أمرين: الأول تشبع صاحبه بالمقاصــد التي تستهدفها الشريعة الإسلامية؛ لأن المقاصد بالنسبة للمفكر المقاصدي هي نقطيـة

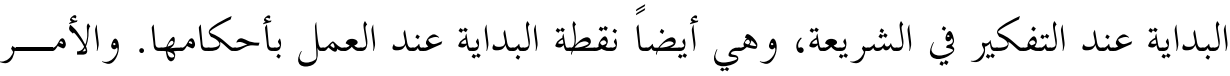
الثاني استناده الواعي إلى عدة منهجية تقدره على اكتشافها وإعمالها في اجتهاده.

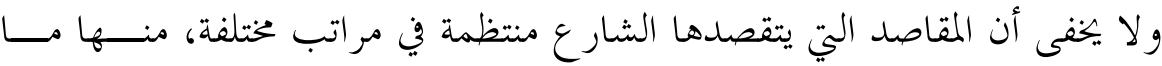
يحتاج في معرفته و استنباطه إلى إعمال الفكر العلمي على اختلاف درجاته، ومستوياته.

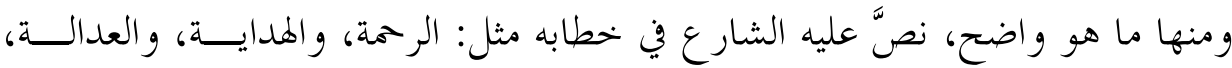

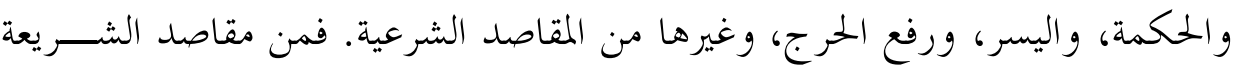

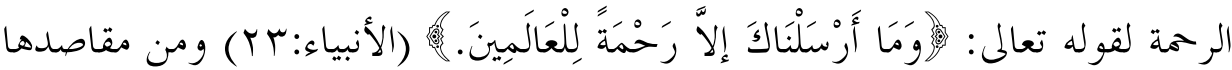

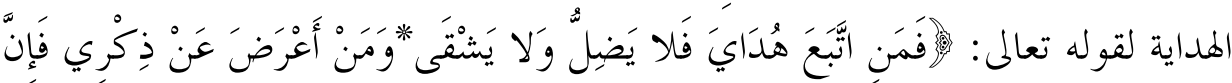

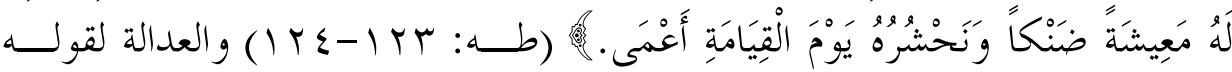

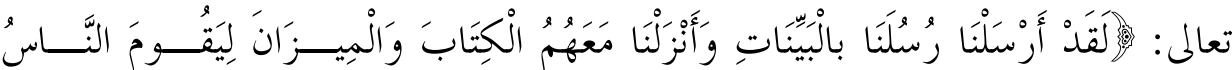

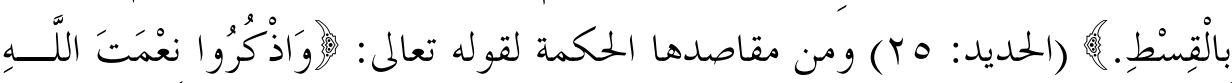

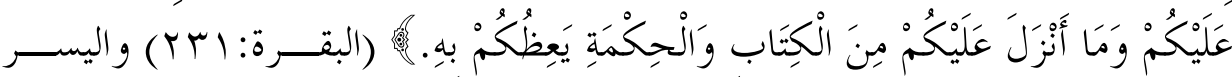

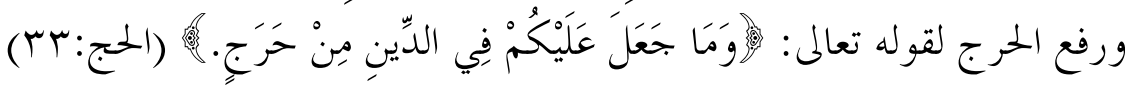
ويتضح من هذا الطرح أن الفكر المقاصدي عُدَّهُ علمية نحتاجها في فقه المقاصــد

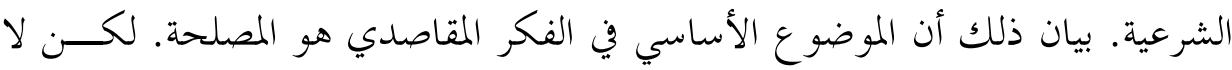

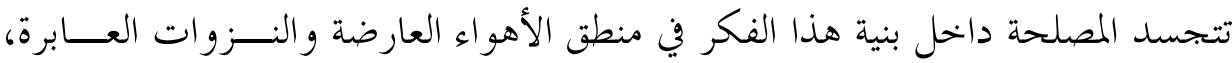
بل المطلوب أن يتسق صاحب هذا النوع من الفكر مع ما يقصده الشارع من مصالح. إن ما يهم عالم المقاصد هو مصالح الناس، لكن ليس بحسب ما يقصدونه فتط، وإنــــا بحسب ما يقصده الشارع. دون هذا الاتساق العلمي مع المقاصد التي يتوخاها الشرع الإسلامي، نسقط في شرك الاختلاف العقيم في مدلولات مفهوم المصلحة، التي يفهمها

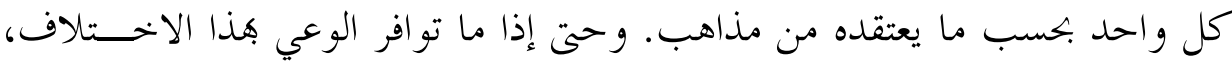




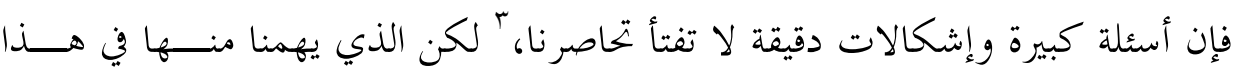
المضمار السؤال الآتي: كيف يسهم الفكر المقاصدي في التفاعل مع الواقع؟

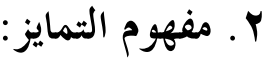

ورد في الكتاب المجيد استعمال مادة (م. ي. ز) في أربعة مواضع: الأول في قولــهـ

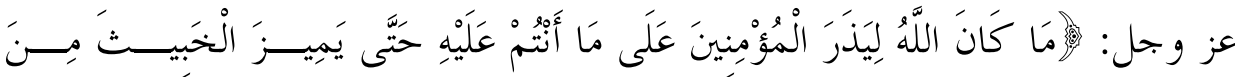

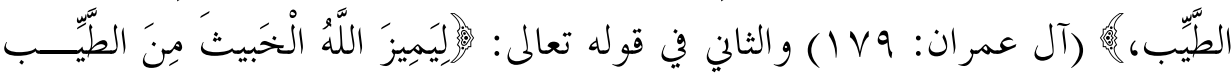

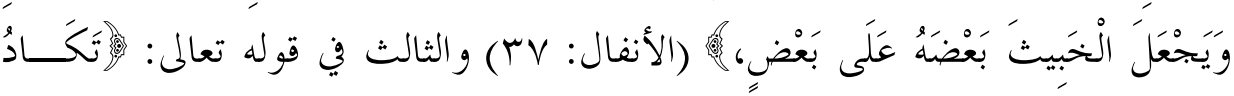

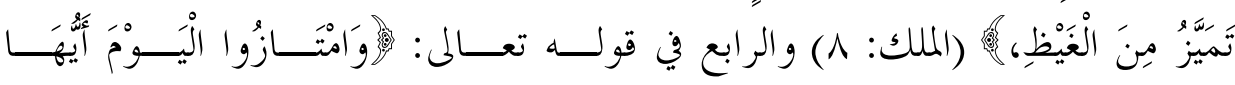

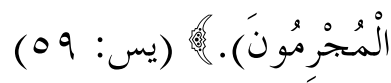

وانطلاقاً من هذه الآيات البينات، يبدو أن المطلوب هو التمييز في مراتب النــاس

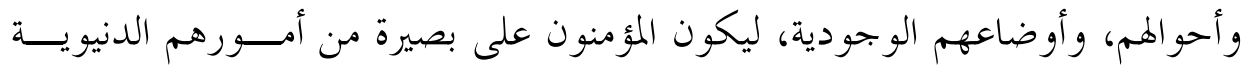

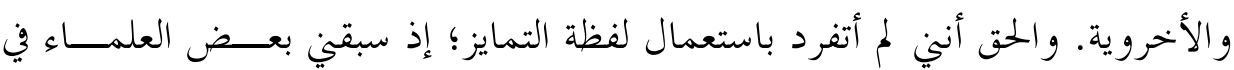
ذلك، لكن في سياقات مغايرة. فقد جعل الإمام ابن عاشور -رحمه الله- من التفكير في التمايز موضوع العلم؛ إذ به يكون "تمييز الحبيث من الطيب. فهو عند ذلك التمييز تفكــير في التمايز." لا شك في هذه الاستعمالات، لكن الذي يعنينا من توظيف هذه اللفظة، الارتقاء بالمعرفة المقاصدية إلى درجة المفهوم الكلي والجامع للمناحي النقدية. وعليــهـ

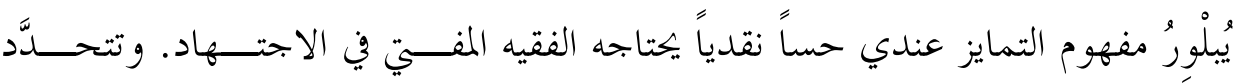

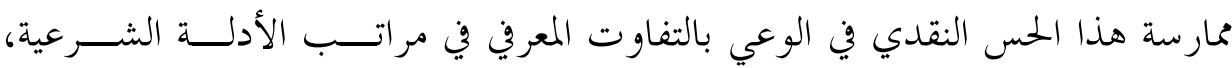
و المصادر الشرعية، والمقاصد الشرعية من جهة، وي الوعي بالتغـــاير الطــارئ علـــى

r منها منها كيف يتحدد الامتداد والشمول الزمني للمصلحة بوصفه موضوعاً أساسياً في الفكر المقاصدي؟ ومنها

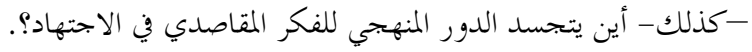

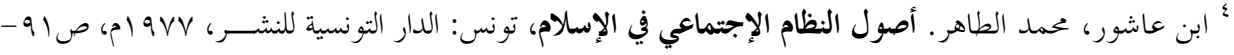


الوقائع والنوازل من جهة أخرى. وبناء على ذلك فالمقصود بالتمايز ذلــك الـــوعي النقدي الذي يفرق به عالم المقاصد بين المراتب المعرفية، المتغيرات الوجودية.

\section{ثانياً: إشكال التفاعل مع واقع الجفاء}

انطلاقاً من الحس النقدي الذي يرسخه مفهوم التمايز، نلاحظ جفاءً مستمراً بين

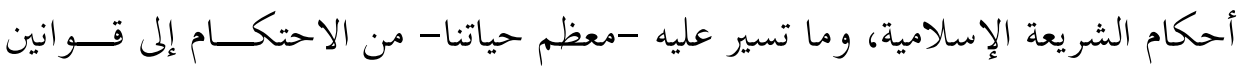
أجنبية مستوردة. ويبدو ذلك على الأقل في مظهرين رئيسين:

المظهر الأول ماثل في أن ثمة قو انين مستوردة تسقط بظلالها علينا على الرغم مــن

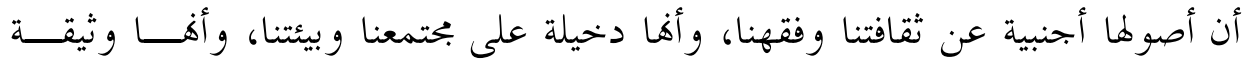

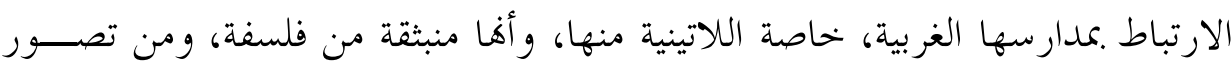
للوجود وللكون ولإنسان مناقض للعقيدة ولأخحاقيات الإسلامية. على الرغم مــن كل ذلك فإها تسيطر على كثير من قو اعدنا التشريعية الضابطة لكثير مــن بحـــالات

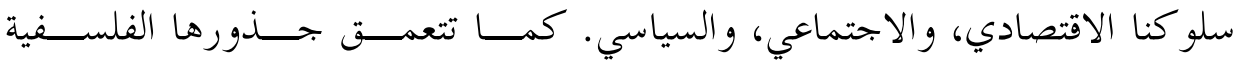
و الأخلاقية في حياتنا جيلاً بعد جيل. وتتدخل بترسانة من القو انين التي تنظم بحـــالات

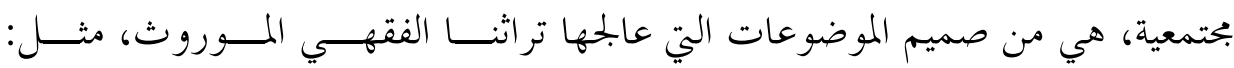

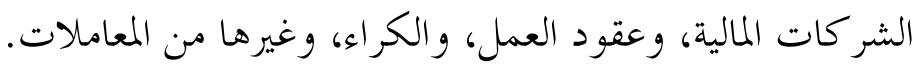

ويتمثل المظهر الثاني في أن هناك أحكاماً موروثة من فقهنا الإسلامي، تطبق هـــــه

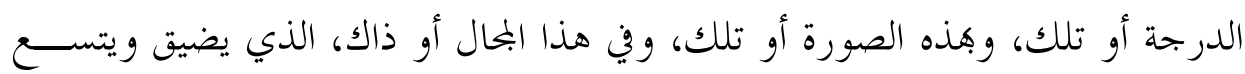
من قطر إلى آخر في العالم الإسلامي. على الرغم من تنظيم هذا الموروث الفقهي لبنائنا البحتمعي في الماضي، وعلى الرغم من أن أصوله ذاتية، مستمدة من الشريعة الإسلامية، ومنسجمة مع فلسفة وتصور للوجود وللكون ولإلانسان منبثقين من مقتضيات العقيدة

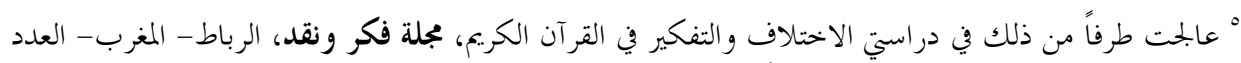

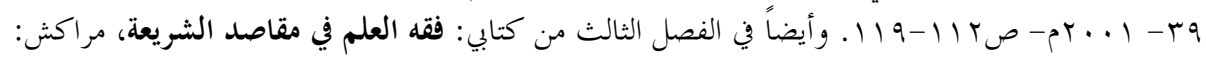




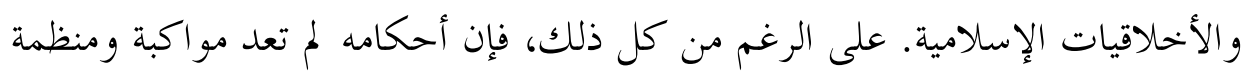

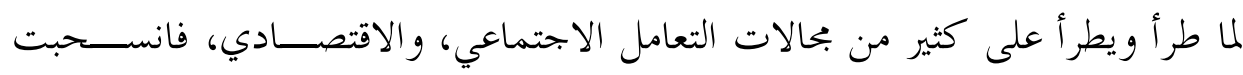

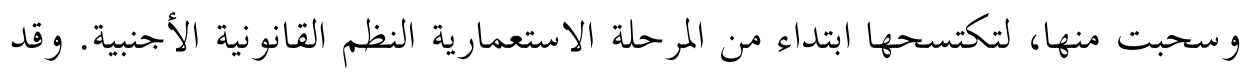

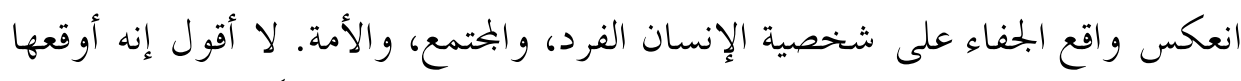

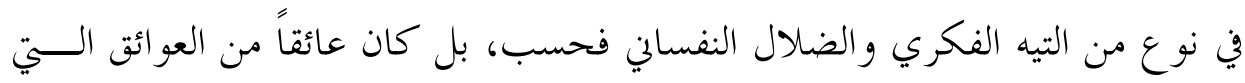

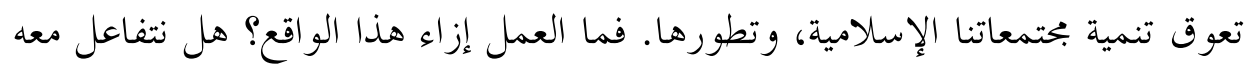

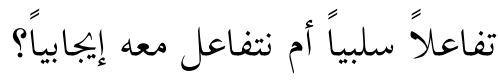

يمكننا أن نميز بين نوعين من التفاعل السبي: أحدهما تفاعل إنكاري والثاني تفاعل

اهز امي.

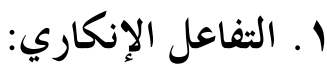

ويستنكر أصحابه واقع الجفاء استنكاراً شديداً، ويرون أن المطلوب هو رفض هذا

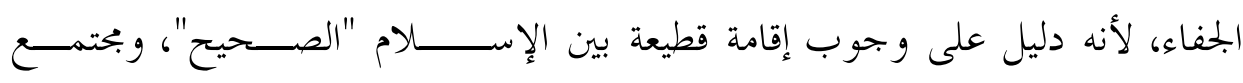

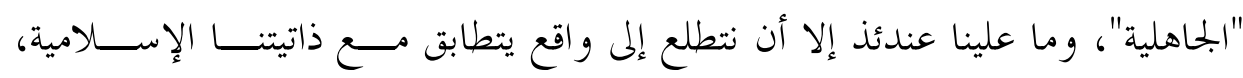

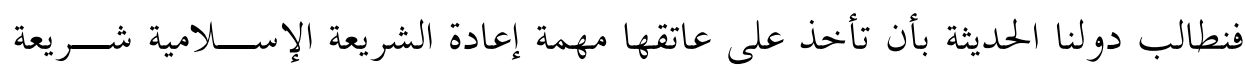

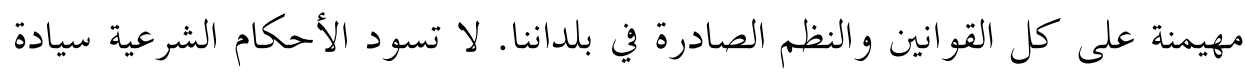

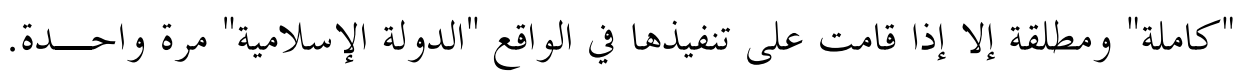

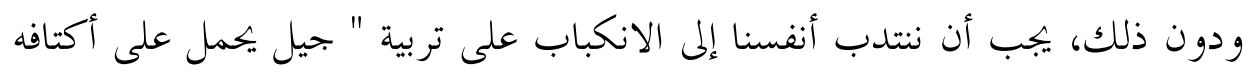

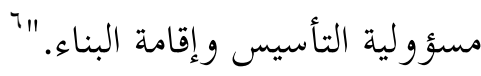

إن في هذا القول منطقاً قوياً من الوعظ الأخلاقــي، والإرشـــــاد التربـــوي، لأن

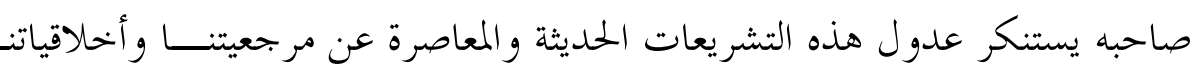

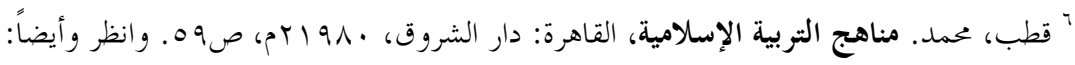

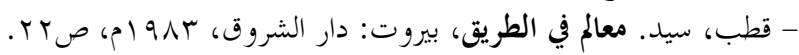




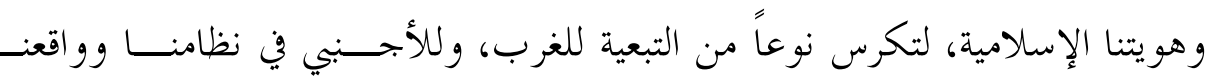
التشريعي، لكنه ضعيف في بنيته و تكوينه الاجتهادي. بل بنحد عند رو اده تعثرً لمبـــادئ ولحقائق مؤسسية في حياة المحتمع المعاصر مثــلـل "الدســـور"، و "الحيــــاة النيابيــة"، و "الديمقر اطية"، و تغليباً عفوياً للعمل السياسي الذي يروم التوثب إلى السلطة وســـيلةً

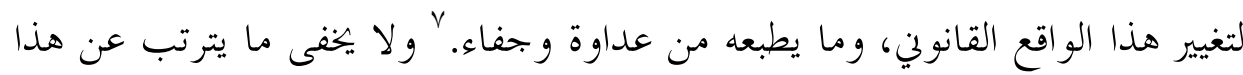
الاختيار من تفاعل سلبي مع البحتمع، وما يستلزمه من قول هجرته ومقاومتــه بكـــل الو سائل، ،ما فيها و سائل العنف و الترويع.

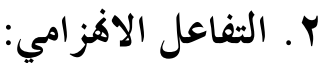

النوع الثاني من التفاعل السبي هو تفاعل اهزامي؛ إذ يرى أصحابه أنه لا ســبيل إلى بتحاوز و اقع الجلفاء إلا إذا أقررنا بأن الو اقع الراهن بتحاوز الشريعة وأحكامها. بيــان ذلك أن الأحكام الشرعية لما كانت مرتبطة بظروفها التي نزلت بشأها فإفا تتغير بتغير الظروف. وعليه لم يعد لأحكام الشرع بمقتضى هذا التغاير المتسارع سلطان على واقع المسلمين في الوقت الراهن. إن أصول التشريع، كما قال بعضهم: " كلها تعقيل للواقع و تنظير له. ولكن الواقع القديم تخطته الشريعة وجاوزه التشريع إلى واقع أكثر تقدماً. في حين أن و اقعنا الحالي الذي يقام التجديد عليه لم يتخطه أي تشريع بعد. و تظل كــلـ

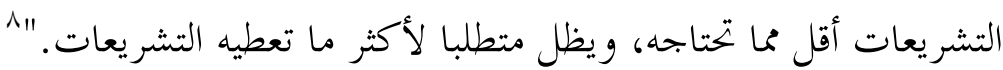

و وي نظري، نفتقر من أجل معالجة واقع الجفاء والعداوة بين أحكام الفقه وأحكام

القانون الضابطة لكثير من بحالات التعامل المجتمعي إلى أمرين: أولمما تفاعل إيجابي مع الواقع، وثانيهما وعي علمي يعمل على تحديد و اضح لمفهوم الواقع.

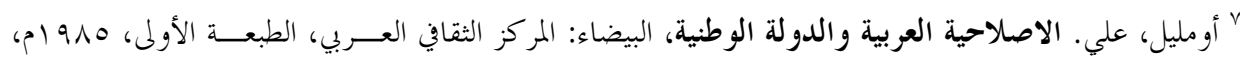

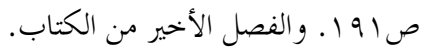

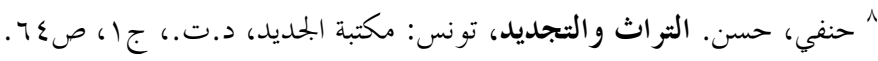




\section{ثالثا: أدلة القول بالتفاعل الإيجابي}

تتعدد أدلة القول بالتفاعل الإيجابي: منها ما يستمد من عقيدة التوحيد في الإسلام، ومنها ما يلتمس في نصوص هذا الدين المختلفة.

وأول دليل على التفاعل الإيجابي هو عقيدة التوحيد في الإسلام. فمــن عقيـــة الإسلام يستمد التفاعل الإيجابي وجوده وشرعيته. فما ينبغي أن يكون عليسهه حسال الإنسال الإنسان المستخلف عن الله تعالى في الأرض، مرتسم في استلهام كل صفات ما سمـــاه

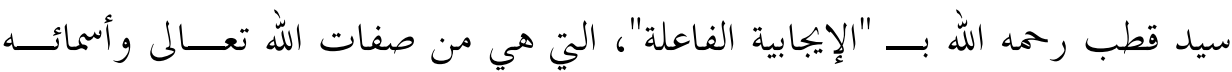

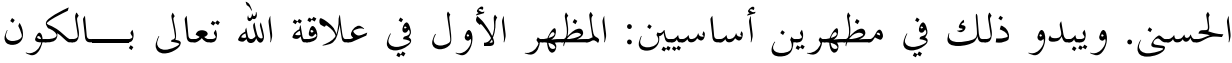

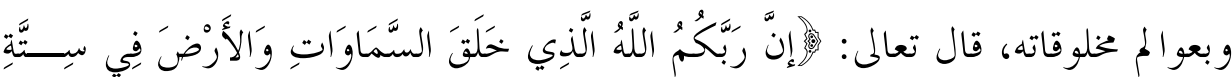

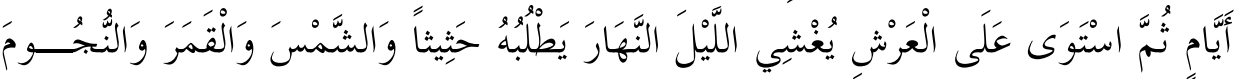

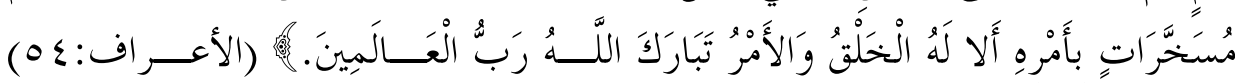

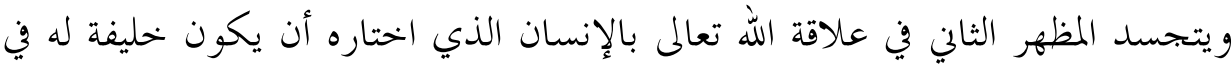
الأرض؛ لأن علمه وقدرته و كل صور عنايته شاملة لكل شؤونه. يطفح القرآن الكريم بكثير من النصوص الدالة على ذلك، ويكفي من ذلك النصوص التي تصور ماعرفتــهـ

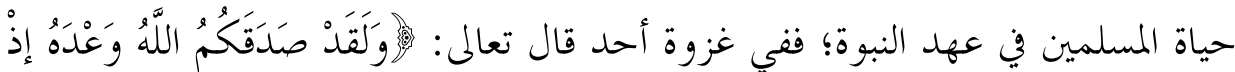

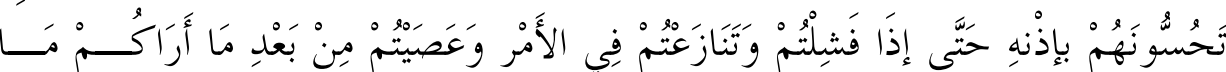

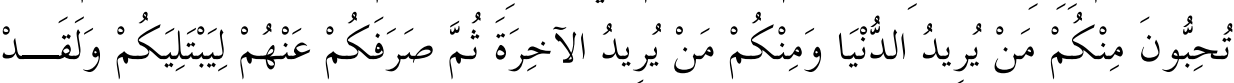

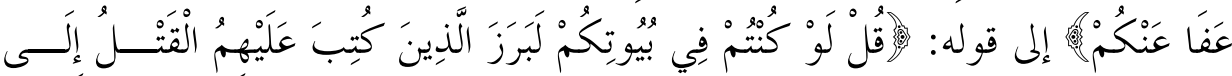

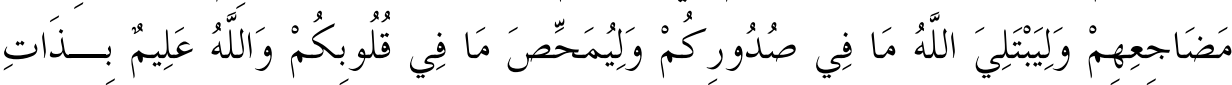

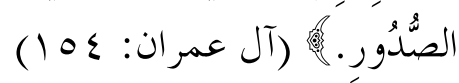

ويجعل كل واحد من هذين المظهرين الإنسان المستخلف عن الله تعــالى عنصــراً

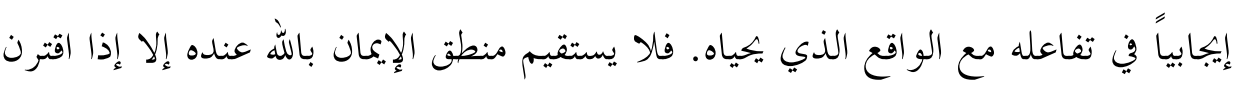

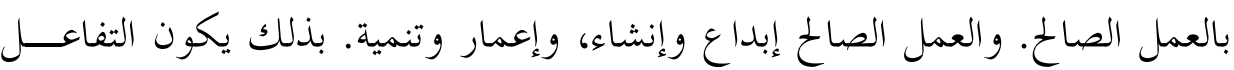

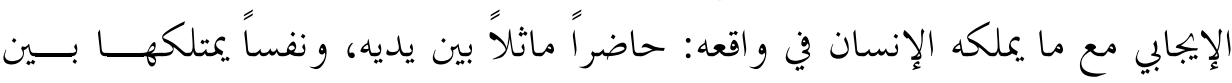




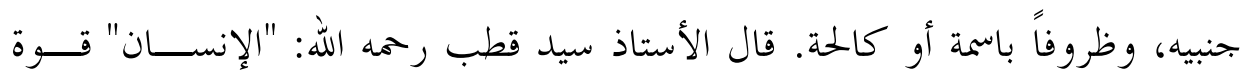

إيجابية فاعلة في هذه الأرض مستخلف فيها ليحقق منهج الله في صــورته الواقعيــة:

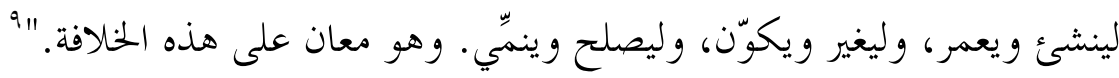

ويلتمس القول بالتفاعل الإيجابي أيضاً من نصوص الكتاب المجيد، فقد جعل القرآن

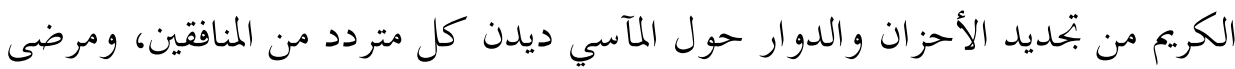
القلوب، الذين تسيطر عليهم التأوهات المنكسرة و التحسر ات المفجوعة.

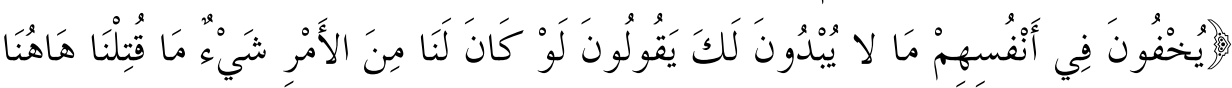

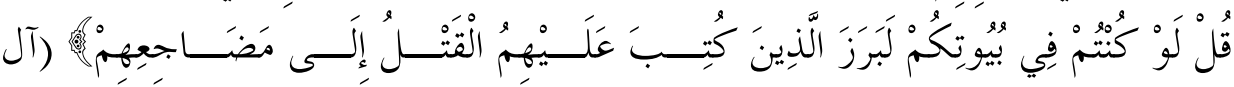

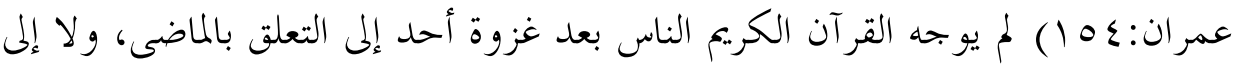
البكاء على أطلاله. بل ربطهم بالمسقبل؛ إذ بيّن لهم علة الهزيمة، ممثلة في التنازع العقيم

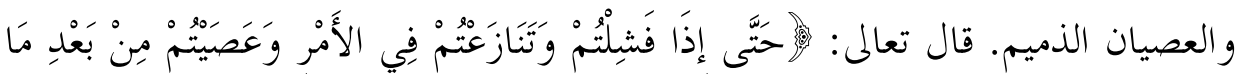

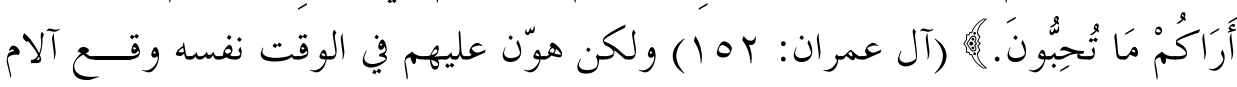

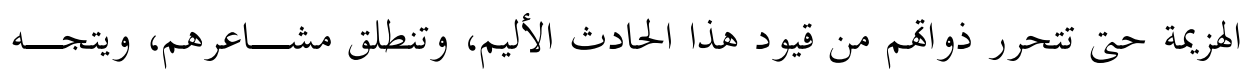

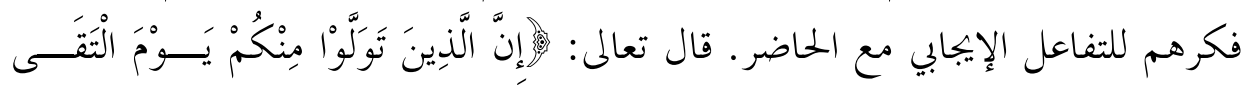

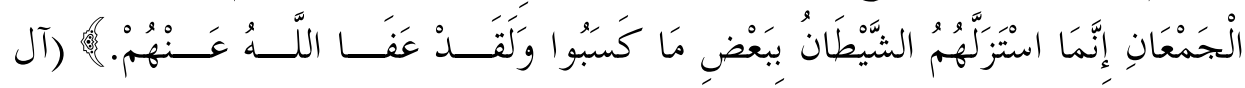

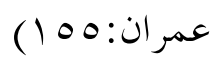

إن العودة إلى الماضي لا تكون إيجابية إلا إذا كانت مفيدة للحاضر. وولا تكــــون

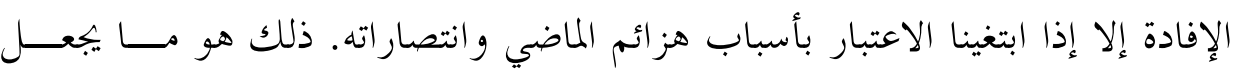

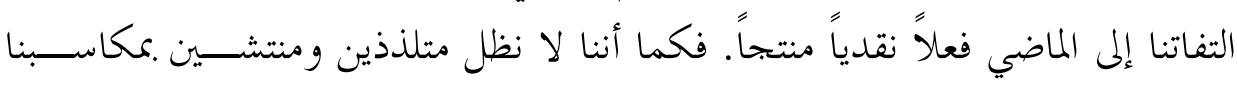

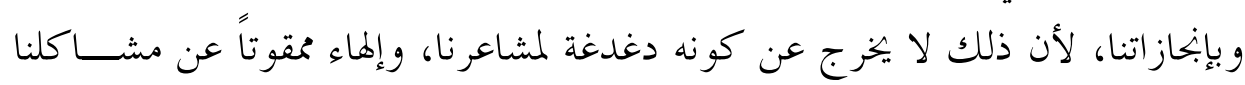

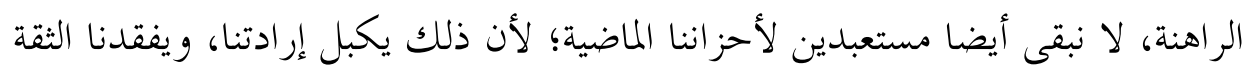

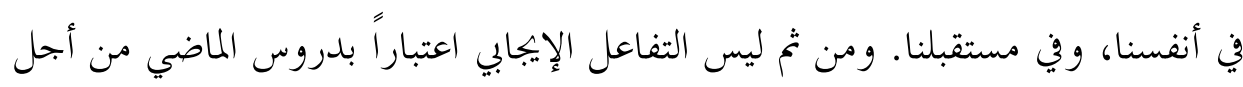
الحاضر واستشر افاً المستقبل فحسب، بل هو بالإضافة إلى ذلك جهد تربوي في تحويل 
الصبر على الآلام و المصاعب، إلى رضى لا يتضمن التسليم ها، بل يتضمن أيضا ذكاء

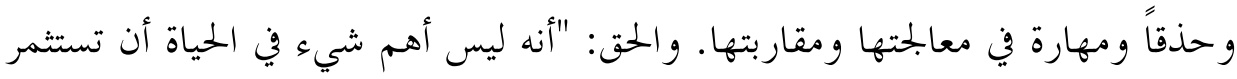

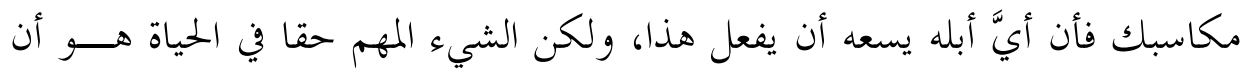

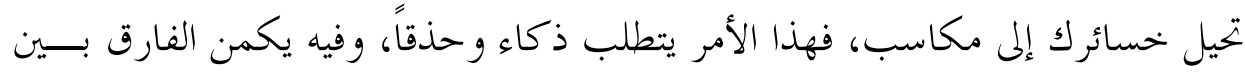

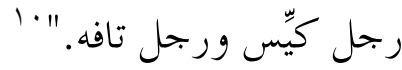

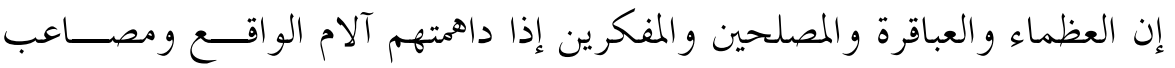

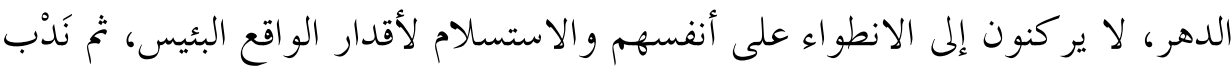

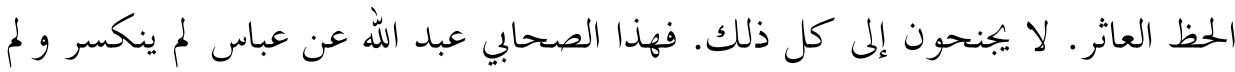

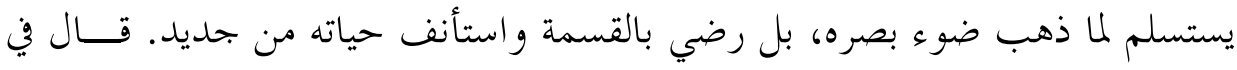

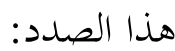

$$
\begin{aligned}
& \text { إن يأخد الله من عينيّ نورهما } \\
& \text { ففي لساني وسمعي منهما نور } \\
& \text { قلبي ذكي وعقلي غير ذي دخل } \\
& \text { وفي فمي صارم كالسيف مأثور " }
\end{aligned}
$$

وعليه، فإن التفاعل مع الواقع أمر شرعي مطلوب، تدل عليه العقيدة الإســامية العامية

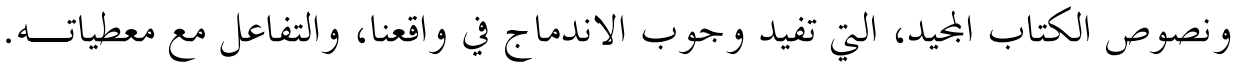

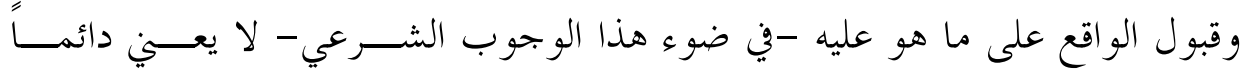

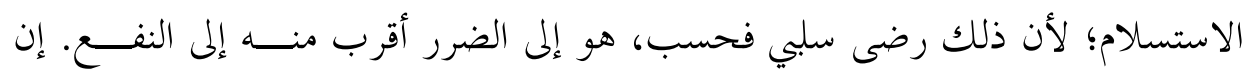

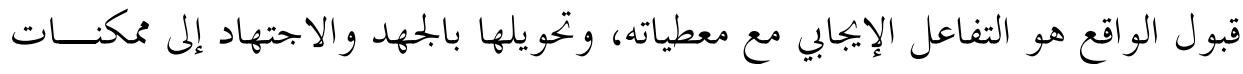

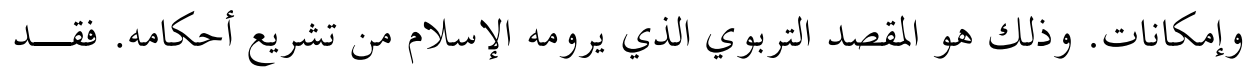

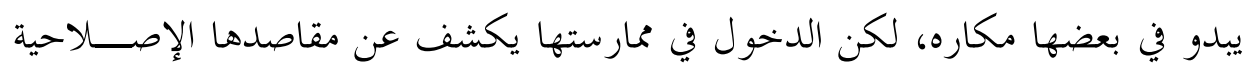




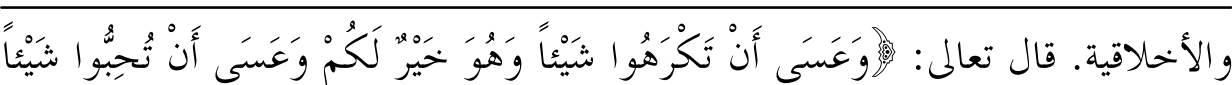

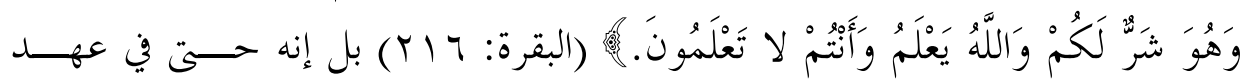

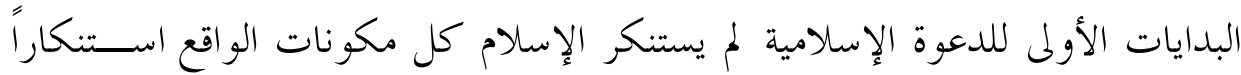

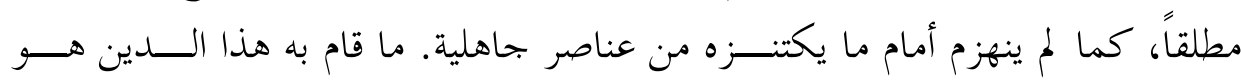
تصحيح ما هو صحيح، والزيادة عليه، كما هو الأمر في الطواف، والسعي، و الصلاة، و الز كاة، فضلاً عن إبطال ما هو باطل كما في تحريم الخمر و الميسر و الربا.

\section{رابعا: الوعي العلمي ومفهوم الواقع}

ليس المهم في التفاعل الإيجابي مع الواقع الإحساس الفرداني بصور الجفـــاء الــتي

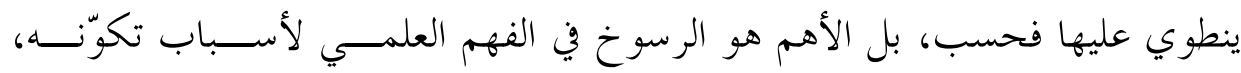

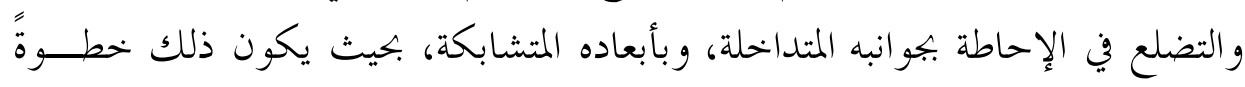

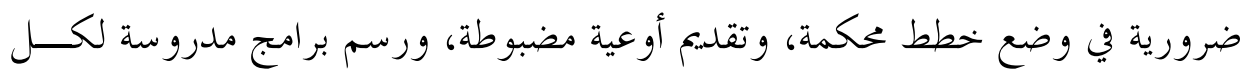
تحرك، ولكل عمل، ولكل تضحية. لا بحال - في التفاعل الإيبابي- للضخ الخطابي الذي يلهب حماسة الجمهور، ولا مكان للحشد اللفظي الذي يستنفر عو اطــف المبتــــئين،

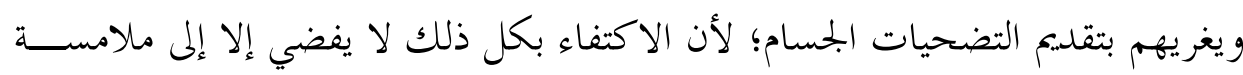

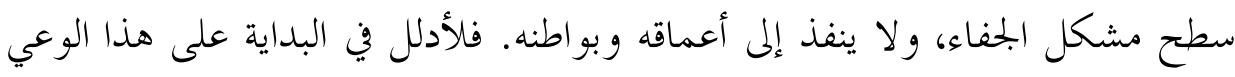
و سنده، قبل أن أتجّه إلى توضيح وجهة نظري في كيفية التفاعل مع واقع الجفاء بـــين

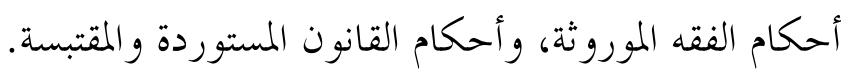

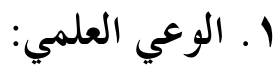

إن العلم ببينات الحاضر ومعطياته المشاهدة، ذو سقف محدود في الزمان، ومرسوم في المكان. فهذا العلم لا تتوقف تغيراته؛ إذ له بداية وفاية، شبيبة وهرم، محيا ومتـــات.

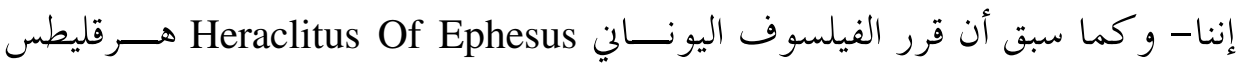




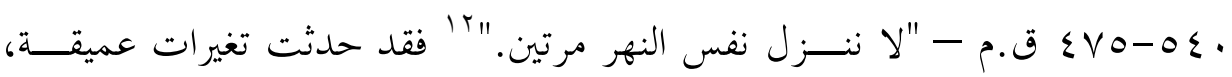

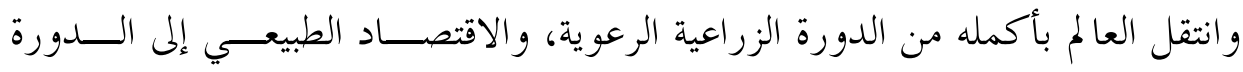

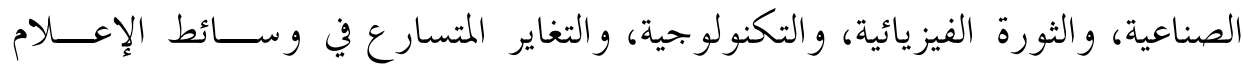
والاتصال، التي هي أسرع من لمحة البصر.

كما أننا نعايش في الوقت الراهن بزو غ شروط عالمية جديدة، وحدوث متغيرات

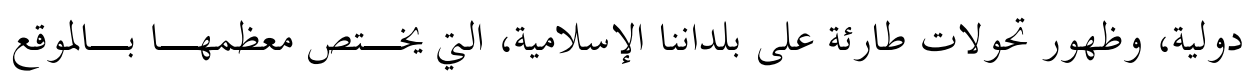
الاستراتيجي المتميز، و بالتفجر السكاني المكثف و المهاجر إلى الغرب، وبقوة الضــغوط

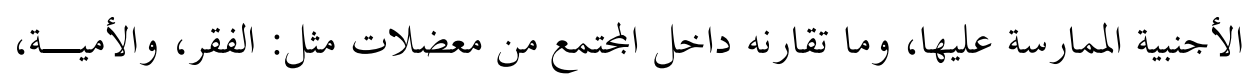
و الإقصاء، و البطالة، و الغلو، و التشدد، و التطرف، ناهيك عن تدخل الدولة الحديثة -

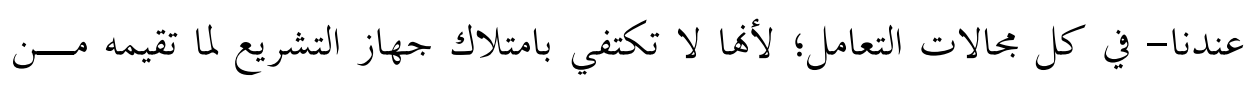
هياكل و نظم، و إنما تمتلك بالإضافة إلى كل ذلك مصدر التشريع فيما تسنه من قـيم، وفيما تصدره من قواعد. كل ذلك دفع ويدفع بالتفاعل الإيجابي إلى واجهــــة اهتمـــام مفكرينا.

إن الوعي العلمي بما تولده معطيات عصرنا الحاضر، ضرورة من ضرورات بنـــاء فكر ناظم للواقع، وليس عقيدة إيمانية، ولا خارقة من الخوارق الكونية. ودليل ذلك أن الله تعالى ربط النصرة بمدى التمسك بالحق، وما يعنيه من علم، وهداية صحيحة. قال

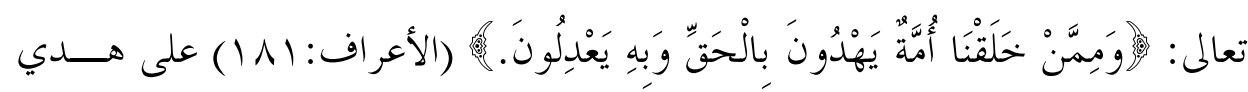

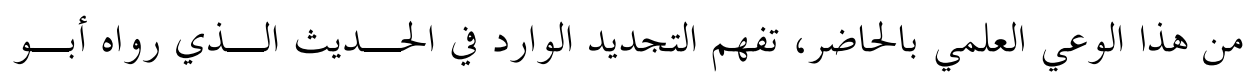

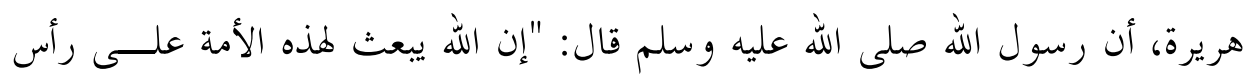

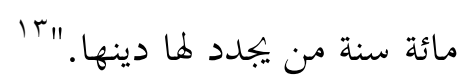

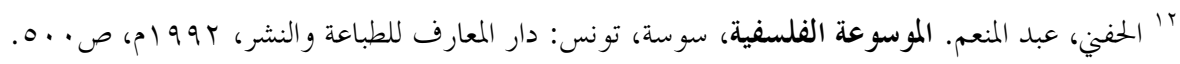

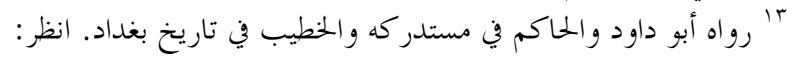

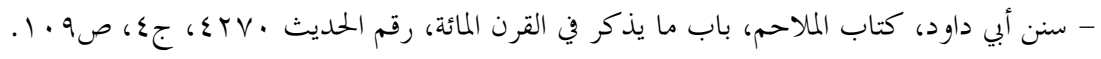




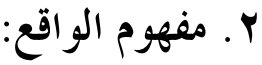

يبدو من الوعي العلمي .معطيات الواقع، أن الخطوة الأولية التي تسبق أي تفاعــل

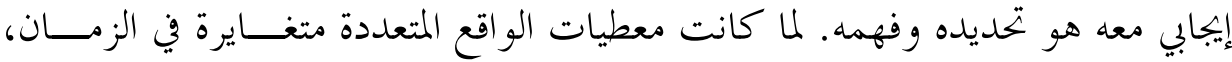

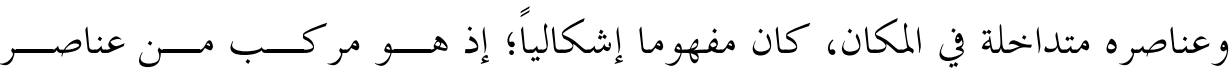

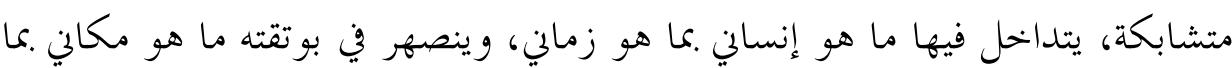

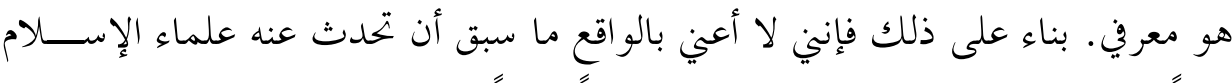

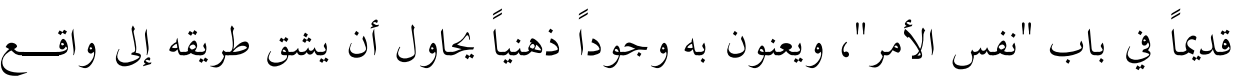

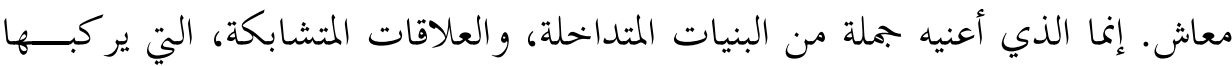

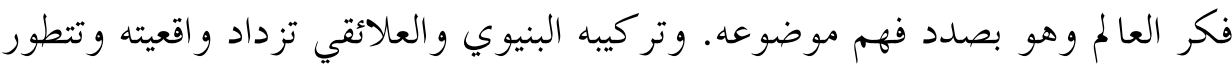

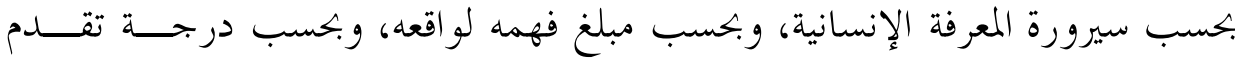

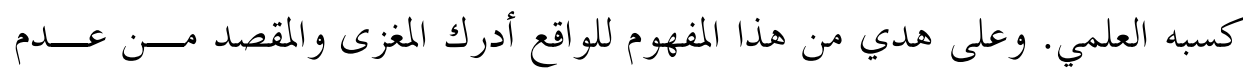

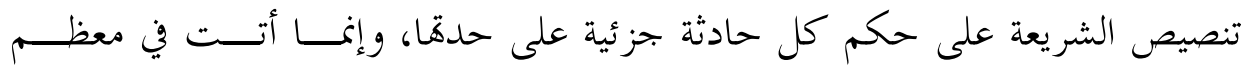

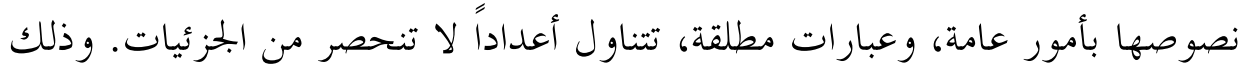

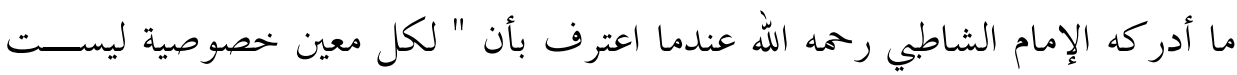

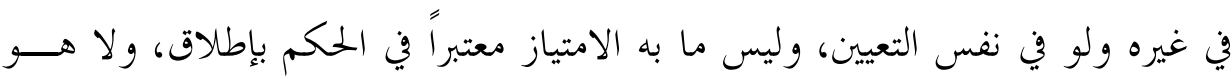

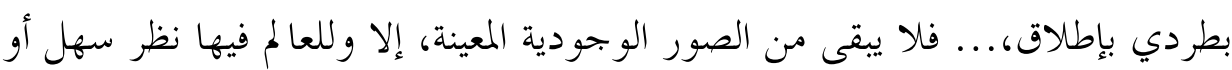

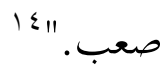

وعليه إن واقعنا الإسلامي - شأنه في ذلك شأن أي واقع بشري وإنســاني - لم

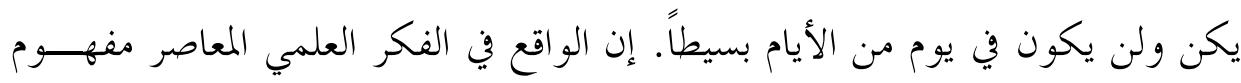

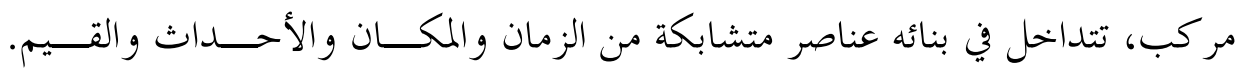

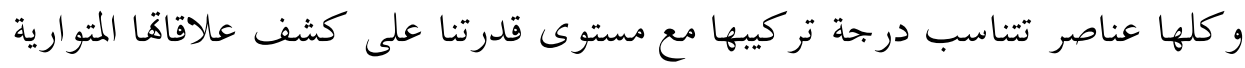

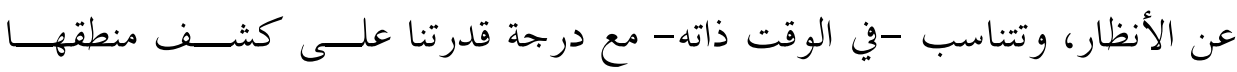
؛' الشاطبي، أبو إسحاق. الموافقات في أصول الشريعة، شرح وضبط: عبداللة دراز، بيروت: دار المعرفـة، ج؛؛ 
الداخلى. وإذا تقرر المنحى التركيي للو اقع الإنساني، ومنه الواقع الإســلامي، فـــلك

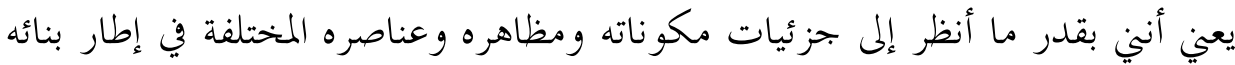
الكلي، أنظر أيضاً إلى بنائه الكلي من خلال المئل المكونات والمظاهر و العناصر الجزئية.

إن و اقعنا الإسلامي الراهن بنيات تتداخل خيوطها وعلاقات تتشابك مكوناهـــــ.

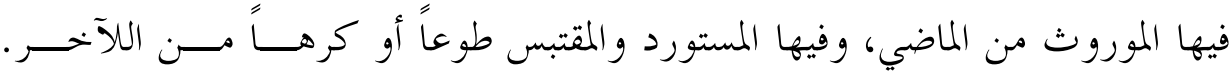

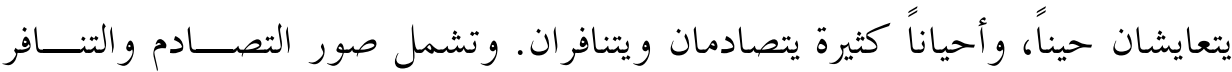

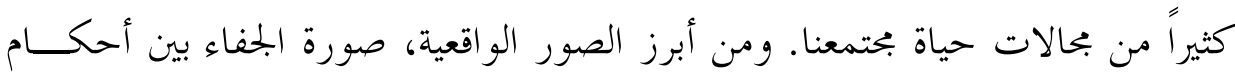

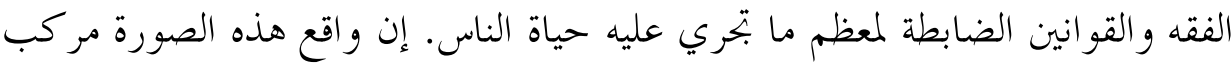

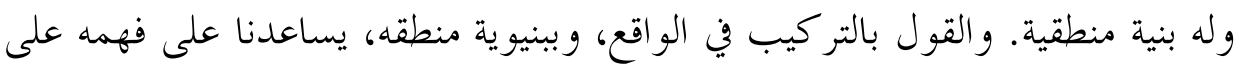

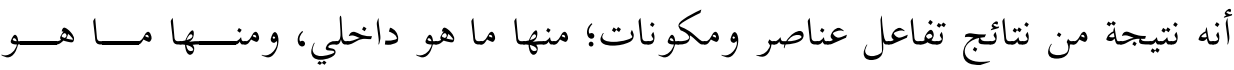

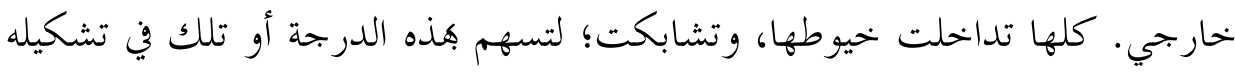

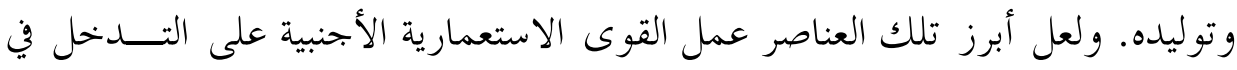

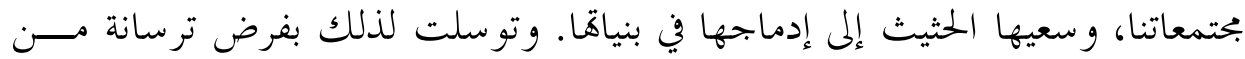

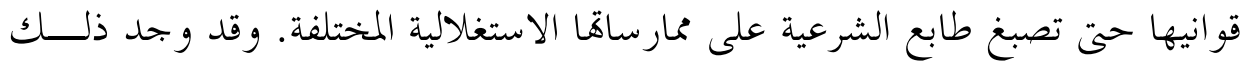

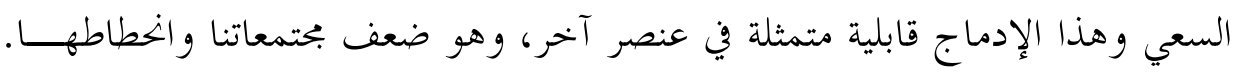

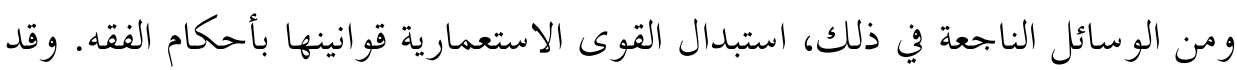

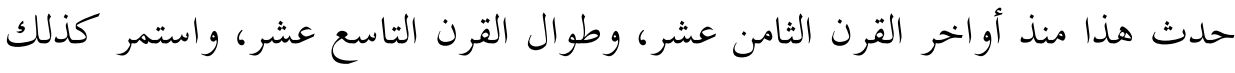

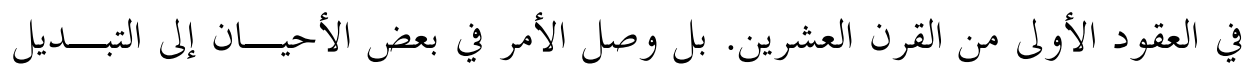
الكلي للأحكام، .بما في ذلك أحكام الأُسرة.

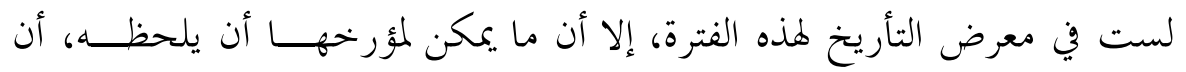

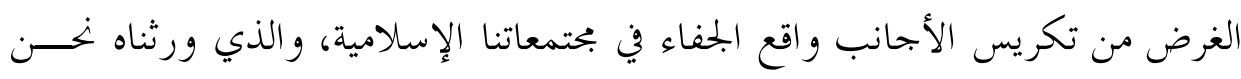

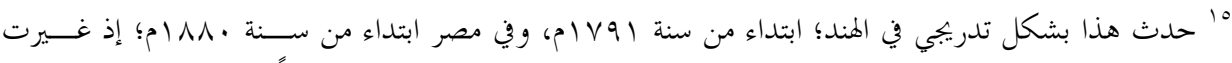

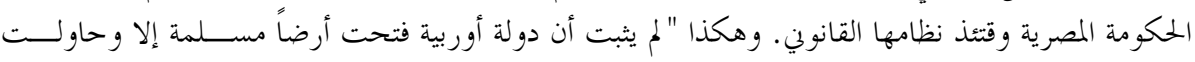

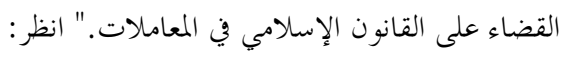

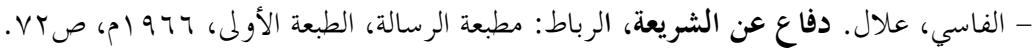


أبناء القرن العشرين والحادي و العشرين، لم يكن هو القضاء على ما ورثناه من أحكام

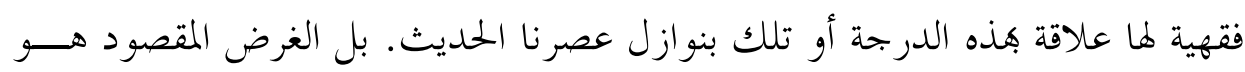
خلق إطار شرعي فلسفي وتصوري نحتكم إليه، يخالف الإطار الديني الإسالامي. فعلى

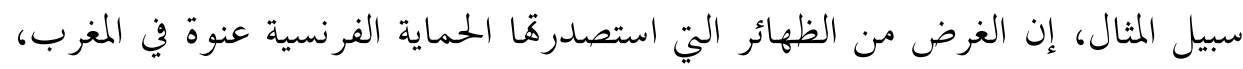

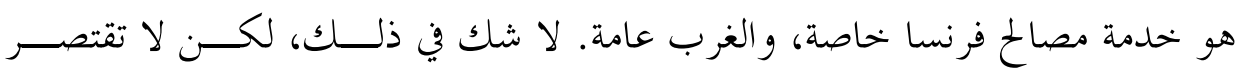
المقاصد الفرنسية هنا على الحصول على الامتيازات الاقتصادية والسياسية، بل تمتد إلى فصل السلوك الاقتصادي والاجتماعي والسياسي للمسلم عن عقيدته التحررية، وفصله

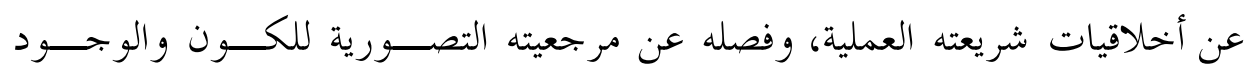
والإنسان.

وإذا أردنا أن نتنفع بموروثنا الفقهي، وأن نتفاعل إيجابياً مع ما ينطوي عليه مــنـ كنوز معرفية، يجب علينا أن نتبصر .كفهوم علمي للواقع، يقدرنا على كشف ورونف أســبابه،

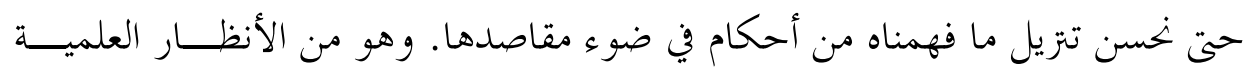
المعتبرة في شرعنا الإسلامي، حتى قال صاحب الموافقات الإمام الشاطبي: "أصل النظر

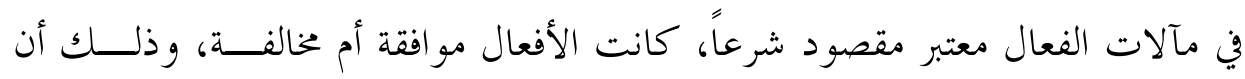

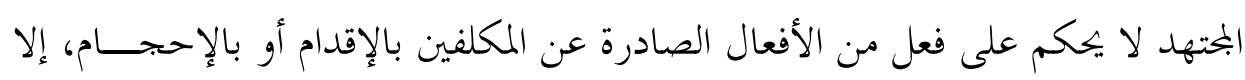

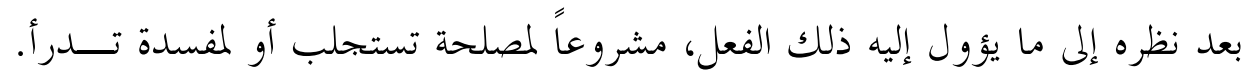

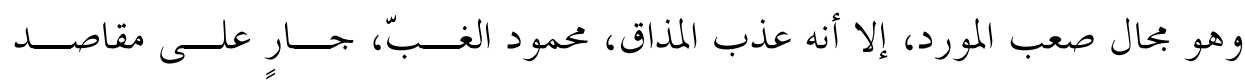

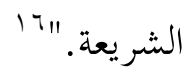

خامساً: الاحتكام إلى مقاصد الثريعة، و آليات الثفاعل الإيجابي مع واقع الجفاء

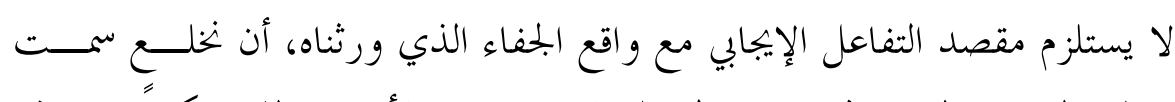

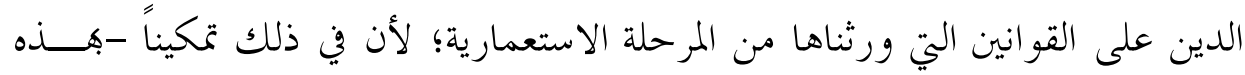
الصورة أو تلك- للوضع القائم.كما لا يستلزم مقصد التفاعل الإيجابي مع واقع الجلفاء 


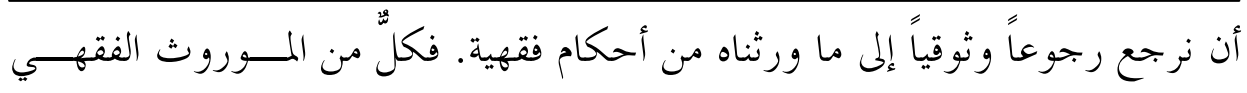
التقليدي، والموروث القانوني الاستعماري إرث مشترك لنا جميعا. والإرث -بطبيعتهكما يتضمن الخسائر والمكاسب.

لا يمكن استلهام التفاعل الإيجابي الذي تنطوي عليه شريعتنا ولا يمكـــن تشــــيله

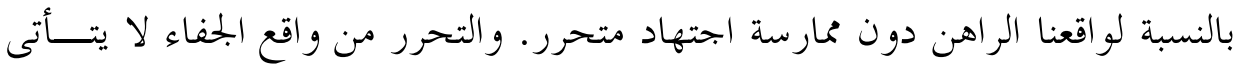

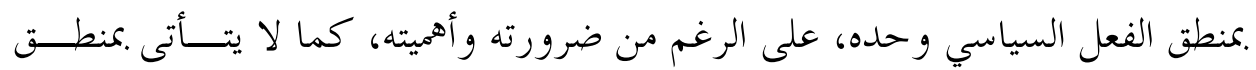

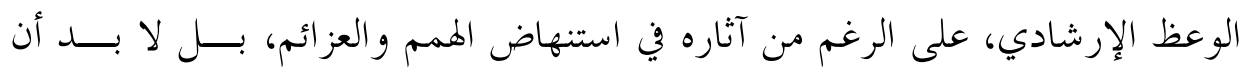

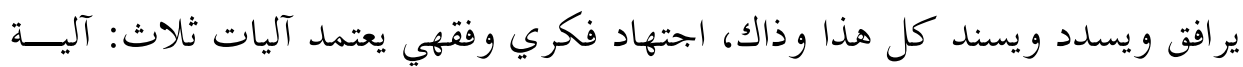

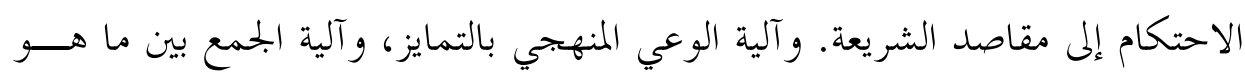

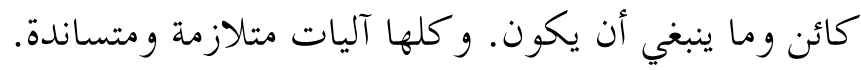

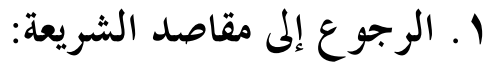

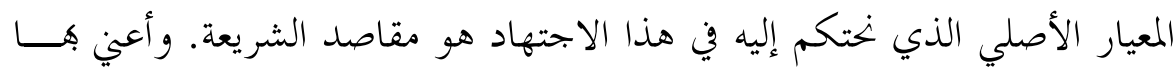

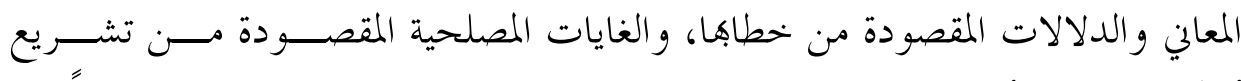

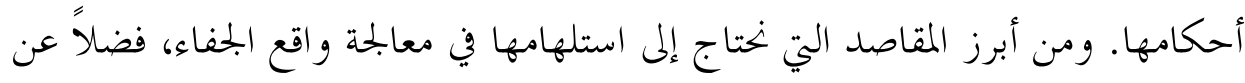

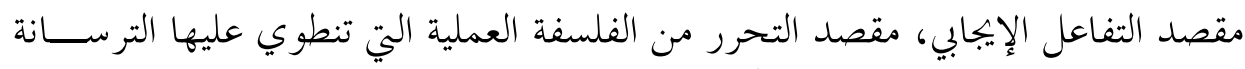

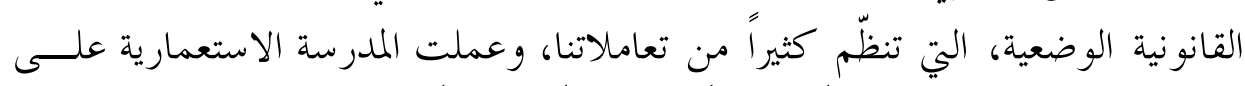

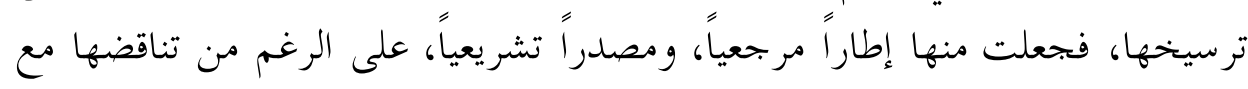

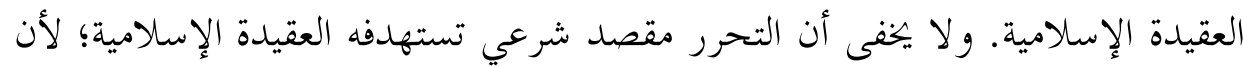

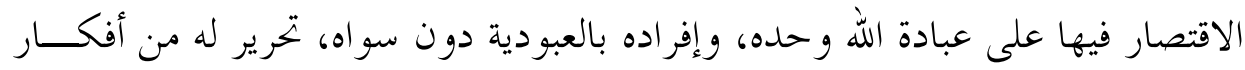

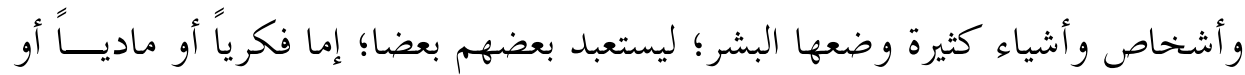
عاطفياً.

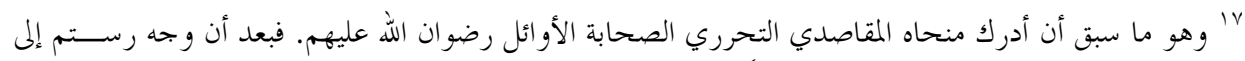

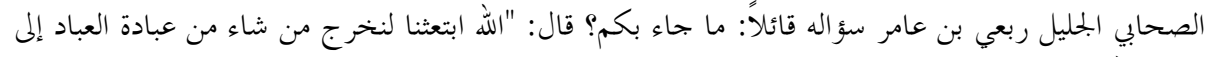

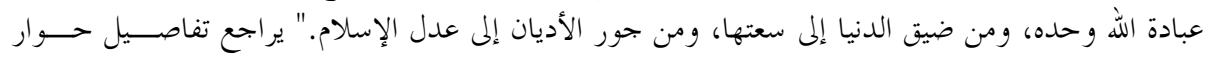

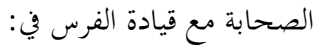


ليس من غرضي هنا تفصيل القول فيما تتفرع عنه مقاصد الشريعة مــن غايــات

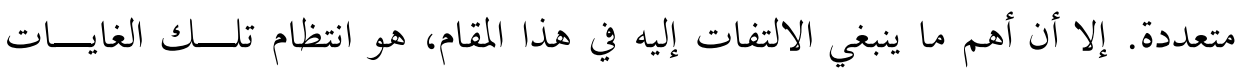

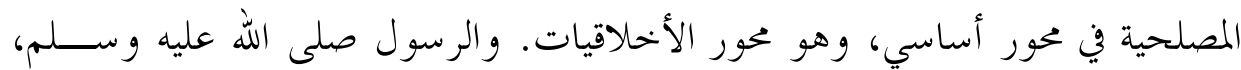

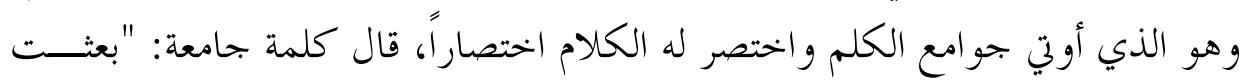

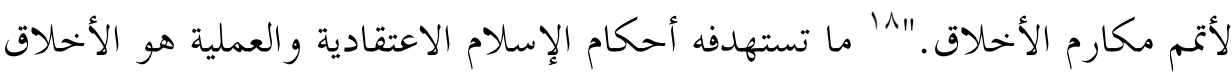

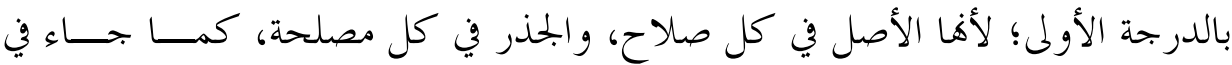

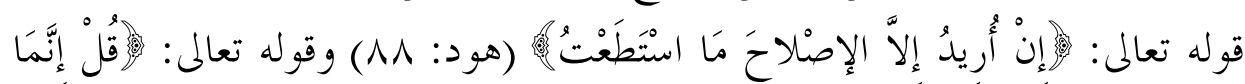

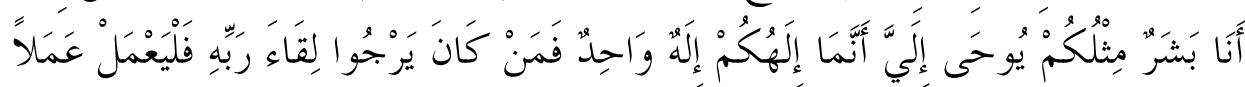

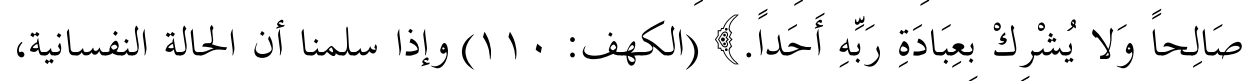

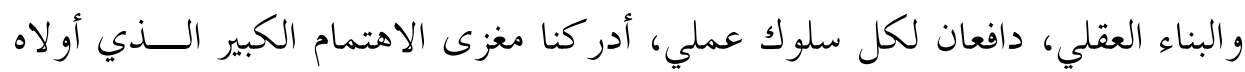

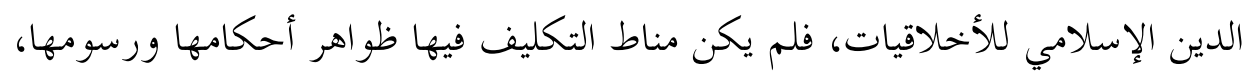

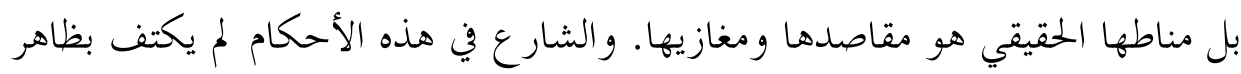

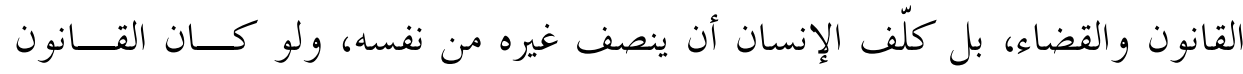

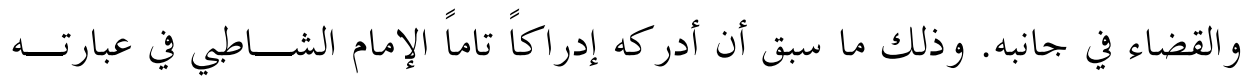

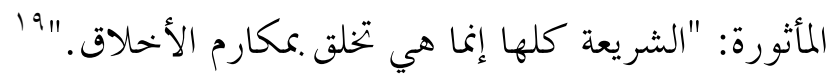

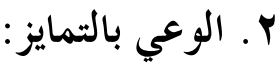

لقد قدم بحتمع الصحابة أنموذجاً خالداً في التخلق .بمكارم الأخلاق في تعـاملاهم

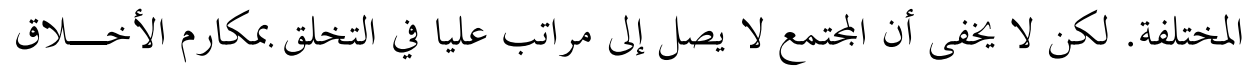

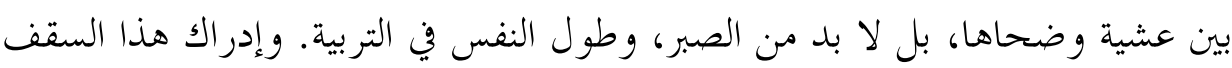

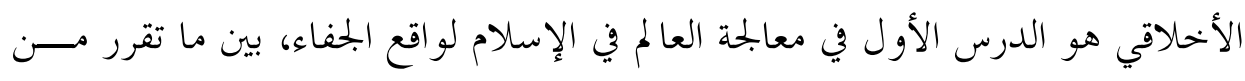

- الطبري، ابن جرير. تاريخ الأمم والملوك، دمشق: دار الفكر، 9V9 (م، جr، صبr، وما بعدها - أحداث

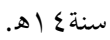
^' رواه البخاري ومالك. ينظر موطأ مالك، كتاب الموطأ، كتاب حسن الخلق.

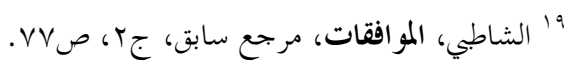


أحكام فقهية موروثة، وما تجري عليه حياة الناس في بجتمعه من الاحتكام إلى قـــــــن انين وضعية مستوردة. ويتمثل هذا الدرس في التمثل الجيد لمفهوم التمايز.

ولكي يرسخ مقاصده في الواقع، تدرج مع الأفراد والجماعات في الأزمنــة، وفي

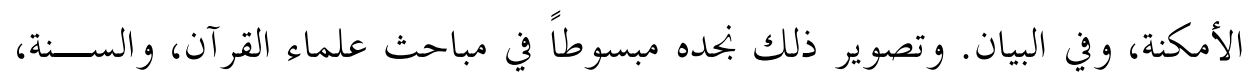

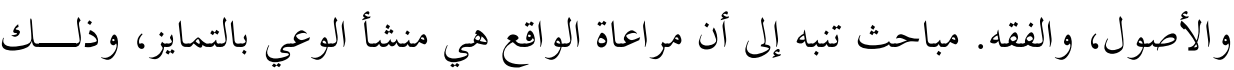

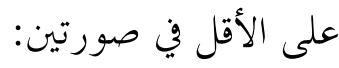
أ. الاختلاف في الأزمنة والأمكنة: كما يبدو من مباحث المكي والمدني، وأسباب

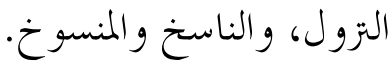
ب. الاختلاف في أساليب البيان. كما يبدو من مباحث الدلالات المقصودة مسنـ

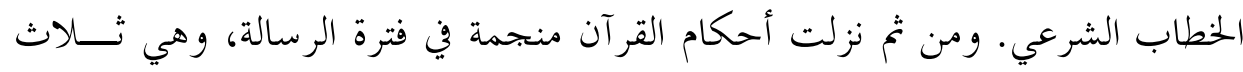

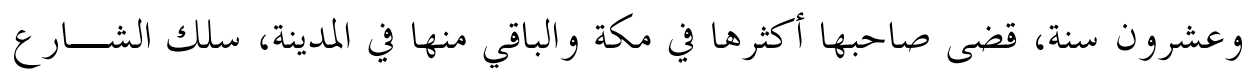

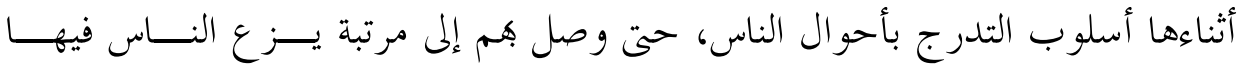
وازع التكليف بأحكام الشريعة و.مقاصدها.

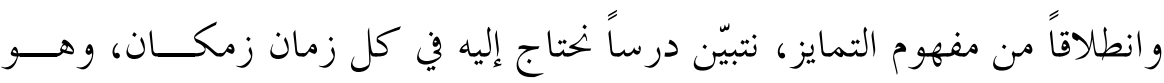

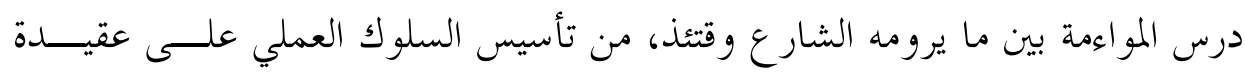

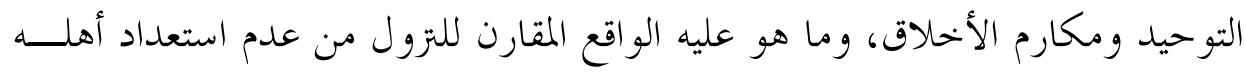

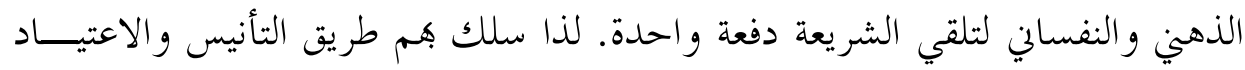

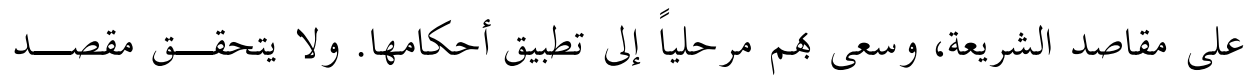

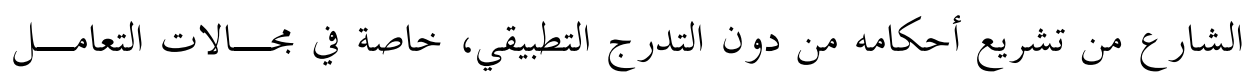

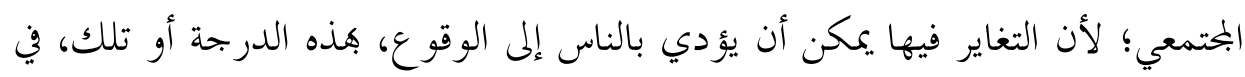


حالة شبيهة بالحالة التي كان الوحي يتزل فيها على رسول الله صلى الله عليــهـ و ســلم

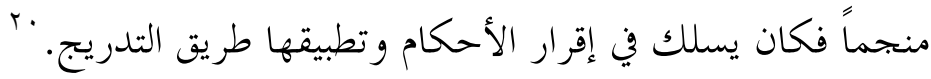

إن من شأن الوعي بالتمايز أن يمكن الفقيه في هذا السياق من أن يضع أي تطبيق للأحكام الشرعية الضابطة للسلوك البحتمعي في حجمه الحقيقي، ووي إطاره الموضوعي، فلا يفكر في أحكام الخطاب الشرعي الضابطة للسلوك المختمعي انطلاقا مـــن منظـــار ظو اهره اللغوية من: بحاز، واستعارة، وكناية فحسب، بل يفكر في الدرجــــ الأولى في تلك الأحكام من زاوية المقامات المختلفة التي سيقت فيها. وبذلك يقبض على المصالح التي استهدفها الشارع من التشريع، ' فيفسح الباب واسعاً لكي يجعل الشاغل الرئيسي

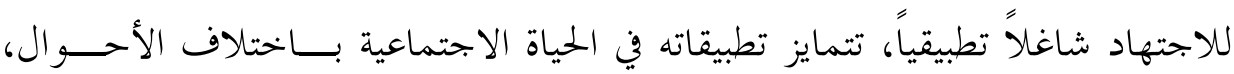
و الأشخاص، و الظروف. كما يمكنّه هذا الوعي، وهو يسعى إلى المواعمة بين مقاصد الشريعة، وما تجـــري

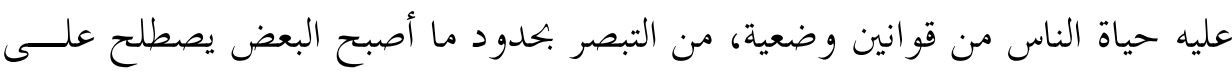
تسميته بــــتطبيق الشريعة". وهم يعنون بذلك تطبيق الجانب القانوني من الشريعة لا

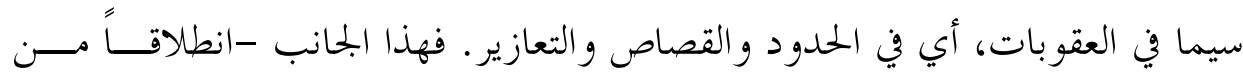
الوعي بالتمايز - لا يمثل كل الشريعة، بل ليس هو عمودها وقوامها وذروة ســـامها،

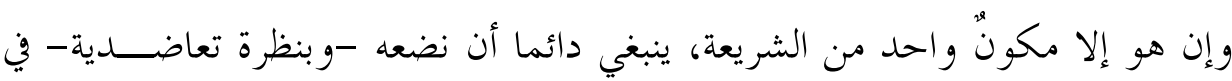

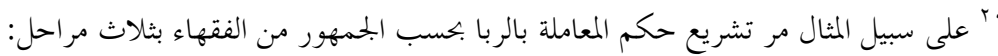

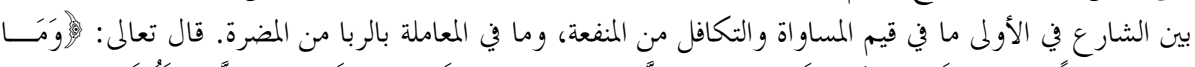

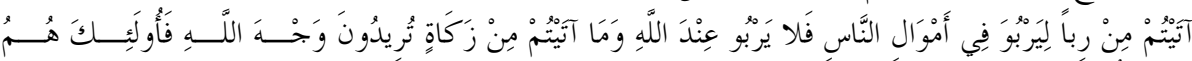

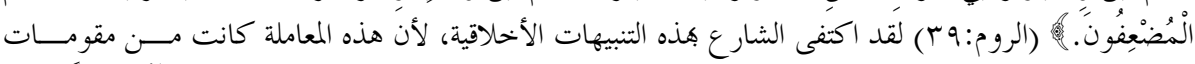

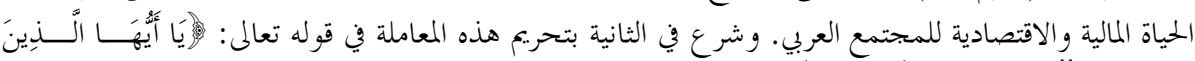

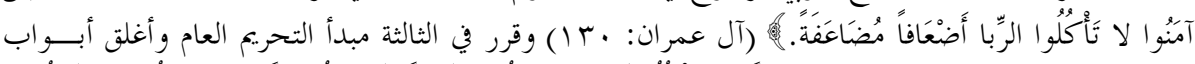

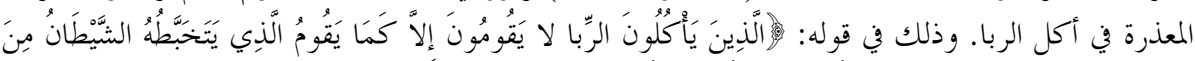

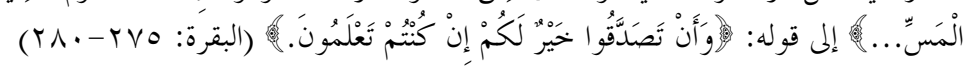

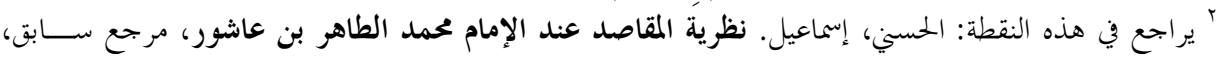




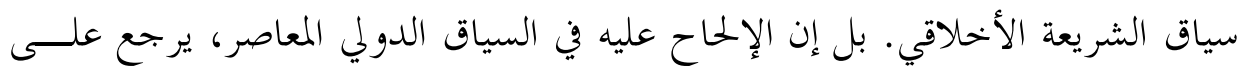

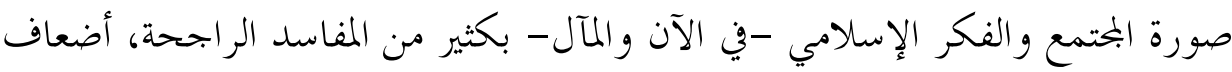

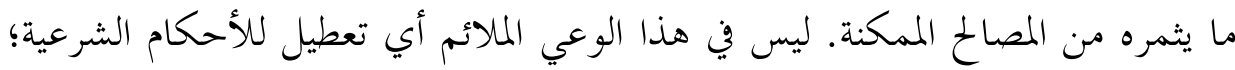

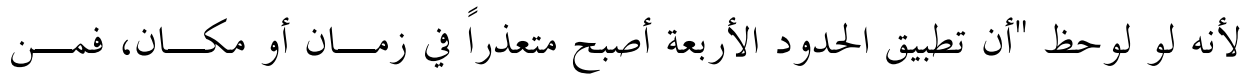

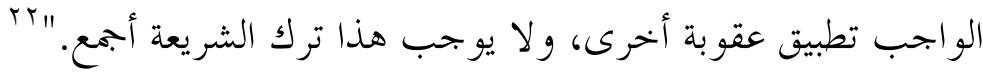

إن الجانب الجنائي في الشريعة لا ينبغي نكرانه، وعدم الالتفــات إليـه، إلا أنـــهـ

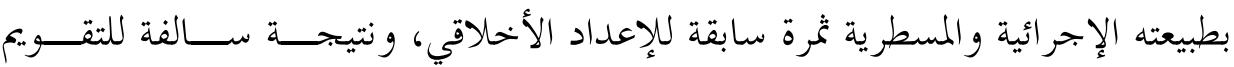

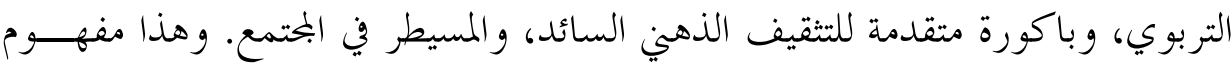

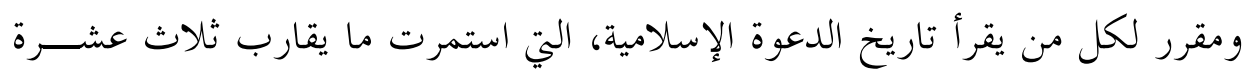

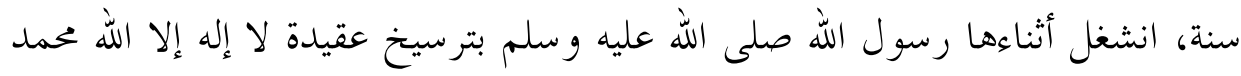

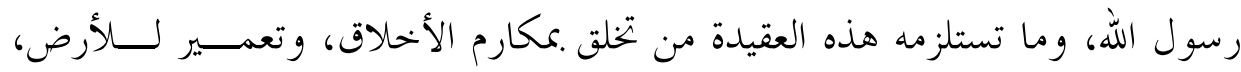

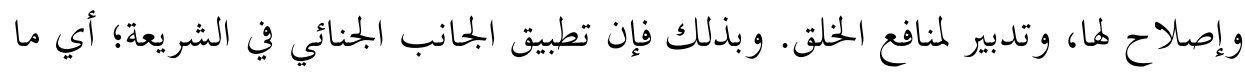

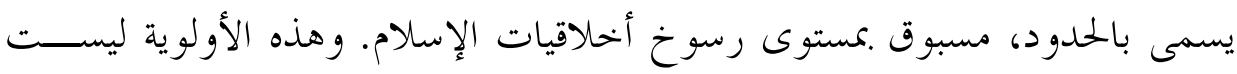

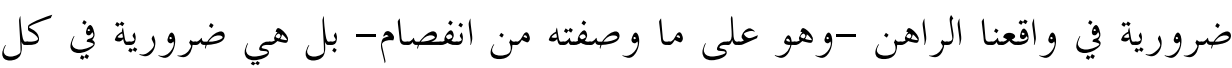

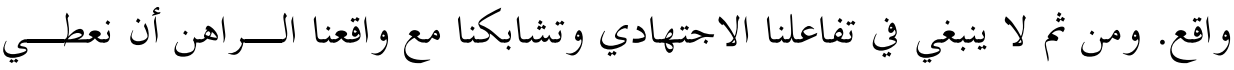

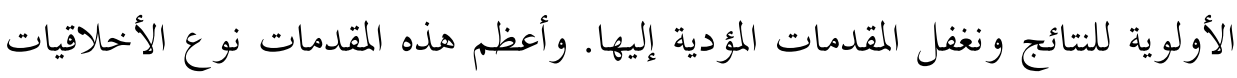
التي تحكم سلوك الناس، خاصة إذا كنا نعيش في حالة بحتمعية يسيطر على أعضــائها المصلحة الذاتية، وحب الذات الشخصية. يمكن أن توجد في البحتمع قو انين للأسرة، وللعقوبــات، بــل وحستى للتجـــارة

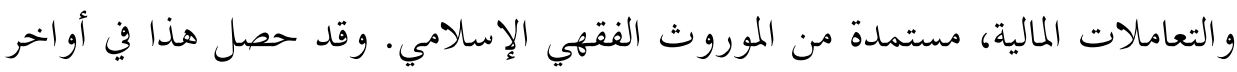

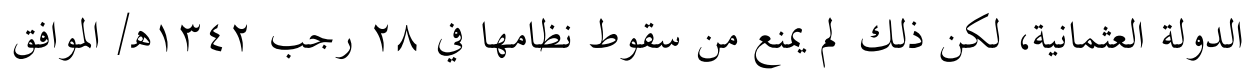

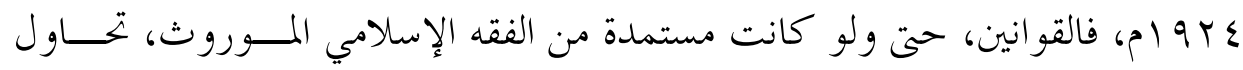


تنظيم الواقع، لكنها لا تصنع وحدها حياة إسلامية جديرة هذا الإسم، قــادرة علــى الحياة، وعلى الإبداع، وعلى المواكبة و العطاء.

\section{ب. الجمع بين الفهم الجرد، وما عليه الواقع الجسد:}

نحتاج في فقهنا للواقع، ووي تفاعلنا معه، إلى وعي دقيق بالتمايز؛ لأن بحرياتــهـ لا تتوقف، وتولد من الأفعال ما لا يكاد يخطر على البال، وهي أفعال متغايرة ومتفاوتة في أسبابها، وفي دو افعها القريبة والبعيدة، وفي نتائجها وأبعادها الظاهرة و الخفية. و وانطلاقاً

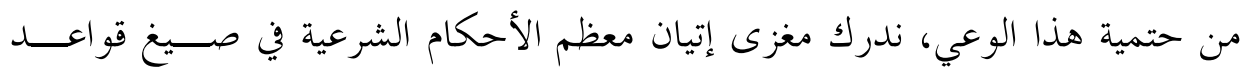
مطلقة، وقو الب كليات عامة لم تتناول من الأفعــال إلا أجناســـها، دون أنو اعهـــا،

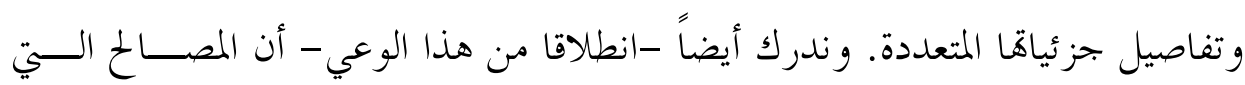
تقصّدها صاحب الشرع من تشريعه أحكامه متفاوتة، وأن الظروف و الأحو ال الــتي تستلهم فيها متغايرة، ومن تخم فكل من يقف جامداً عند دلالات النصوص الشـــرعية، ولا يطوف بفكره في الزمان، ولا يجول بنظره في الوقت و حكمه، يجمد على الفهـــوم الموروثة، والأنظار المتقادمة. وتلك - في نظري- هي الجناية الحقيقية علــى الأحكـــام الشرعية، بتفويت مقاصدها، وبإظهارها في مظهر غير ملائم لما يستجد من الظروف، و الأحو ال المتغايرة.

وتأسيساً على هذا الوعي يتعين الجمع المتآلف بين ما ينبغي أن بتري عليه حيــاة

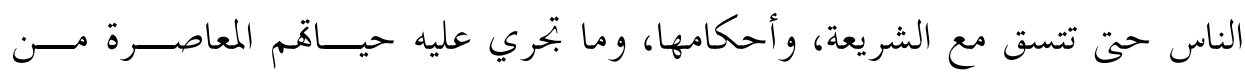
الاحتكام إلى قو انين وضعية مستوردة. لا يكفي العلم البحرد بالأحكام و.مقاصدها، وإن بلغ ما بلغ من دقة الفهم لبنيتها ولمقاصدها، بل لا بد أيضا من العلم البحســــــــــالو اقع و التعقل التجريي لما عليه من جريان معظم مناشطه، وفق القو انين المستوردة. ويتمثــلـ

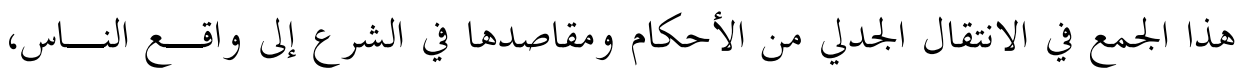
و الانتقال مرة أخرى من واقع الناس هذا إلى الأحكام ومقاصدها. و ونفحص في هـــــا 


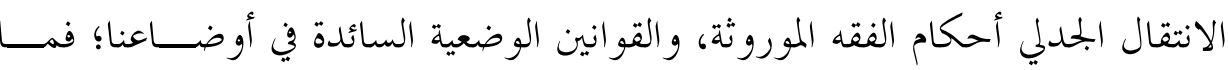
تآلف منها مع مقاصد الشريعة في جلب المصالح ودرء المفاسد أقررنا بــه، و جلينــاه للأمة، و البحتمع دون مزايدات، وما تصارع نبهنا إليه، وو كلنا أمــــه إلى المســـؤولين

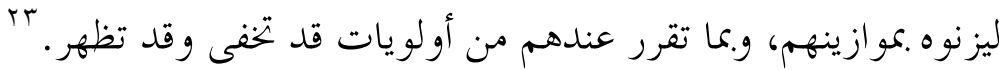

نختاج هذا الانتقال الحي والجملي في قراءتنا ودراستنا لترسانتنا القانونية المعاصــرة.

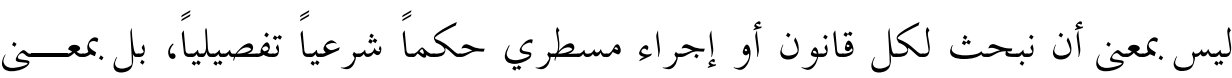

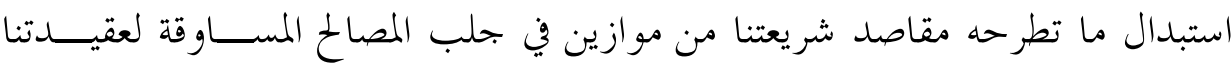
وأخلاقياتنا، ومن مقاييس في درء للمفاسد المناقضة لمما بالفلسفة الثاوية خلف هــــهـ

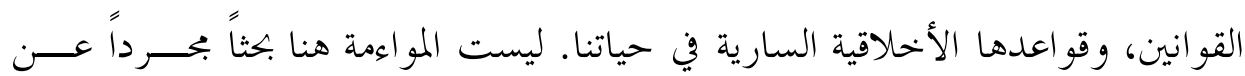
مبررات وقتية، وإنما هي اجتهاد مبني على أدلة علمية من و اقع الشريعة، نبرهن هـا على شرعية كثير من التعاملات المستجدة أو عدم شرعيتها، خاصة التعاملات التي لم يهــتم

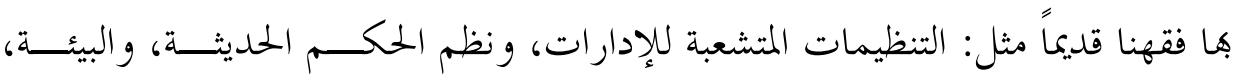
ومعاملات الأجواء والبحار، و المصارف، وغير ذلك من المؤسسات و البنيات الــتي لم تكن تخطر على بال فقهائنا رحمهم الله.

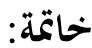

و الحاصل من هذه الدراسة أننا في إشكال التفاعل مع واقع الجفــــاء إزاء تفاعــل سبلي وآخر إيجابي. فبالنسبة للتفاعل السبي نميز بين اختيارين: أحدهما تفاعل إنكاري يستنكر أصحابه و اقع الجفاء استنكاراً شديداً، ويتطلعون إلى واقع يتطابق تطابقاً تامـــاً

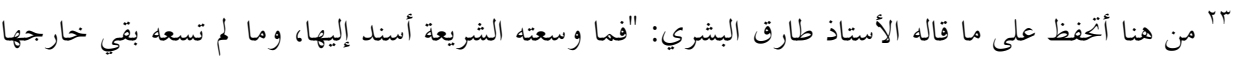

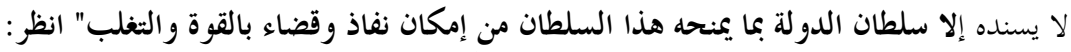

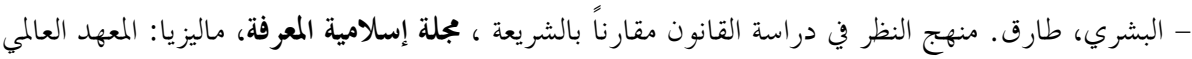

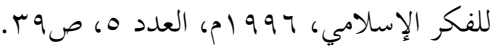




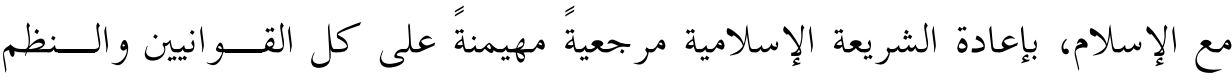

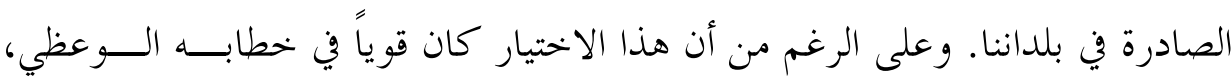

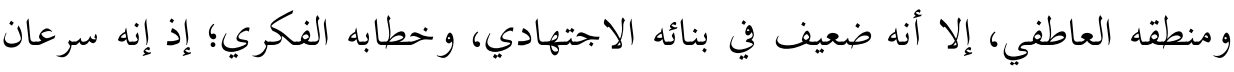

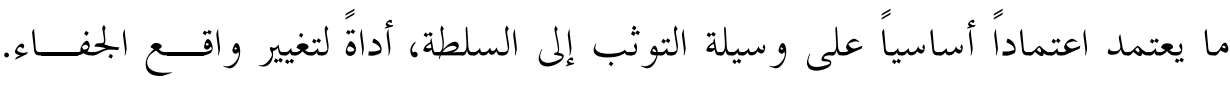

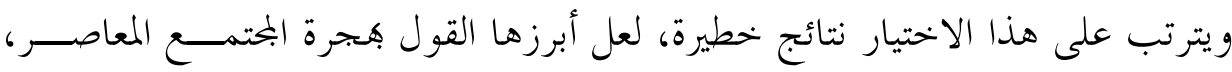
و السعي إلى رفضه بكل الوسائل، مما فيها وسائل العنف و الترويع. و الاختيــار الثـــاني

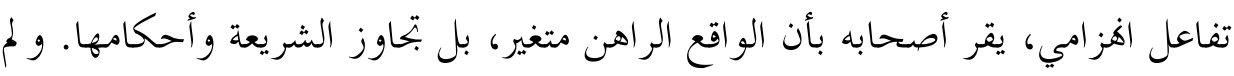

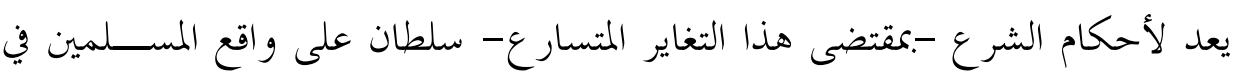

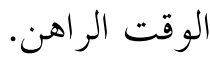

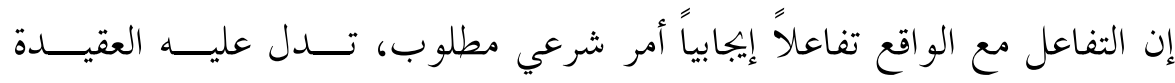
الإسلامية، ونصوص الشريعة الإسلامية. و كلها تفيد وجوب الانــــماج في واقعنــا،

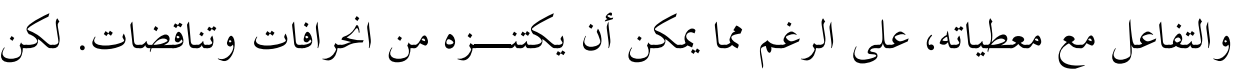
المهم في التفاعل الإيجابي مع الواقع، هو الرسوخ في الاستيعاب العلمي لأسباب تكون بنيته، والتضلع المنهجي في الإحاطة بيجو انبه المتداخلة، وبأبعاده المتشابكة، بوصف بـ ذبع ذلك

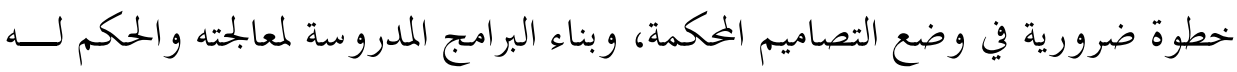

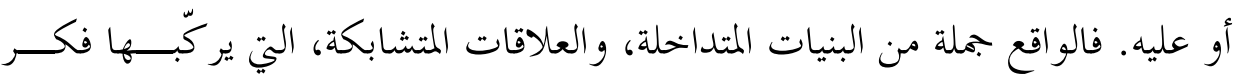

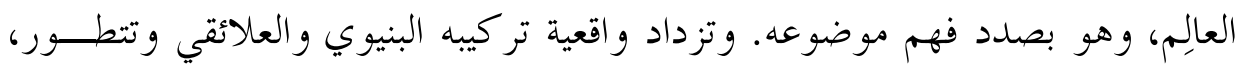

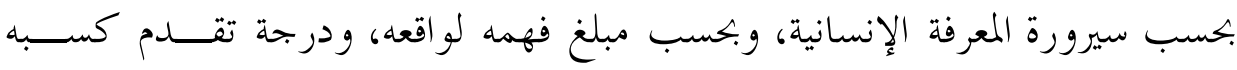

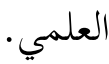

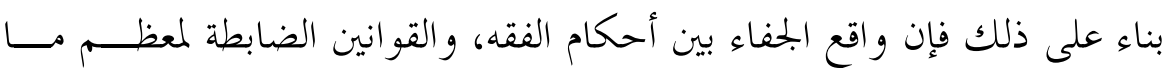

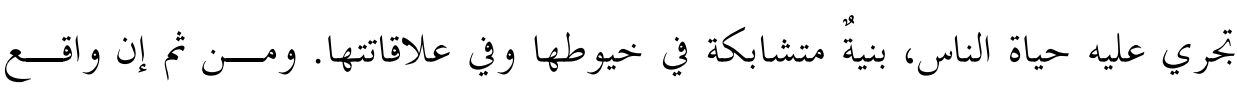
الجفاء في بلداننا الإسلامية مركب، وله بنية منطقية. والقول بالتركيب، وبالبنيويسـة في 
هذا الواقع، أداةٌ علمية تساعدنا على فهمه نتيجةً من نتائج تفاعل عناصـــر متعـــدةة، ومكونات مختلفة: منها ما هو داخلي، ومنها ما هو خارجي وهي عناصــر تــــــــت خيوطها وتشابكت لتسهم هذه الدرجة أو تلك في تشكيله وتوليده. ولعل أبرز تلــك كـ العناصر؛ ضغوط القوى الاستعمارية الأجنبية الاقتصـــادية و السياســية و العســكرية، و سعيها الحثيث إلى إدماج البحتمعات الإسلامية في بنياها حتى تكون تابعة لها. وتوسلت

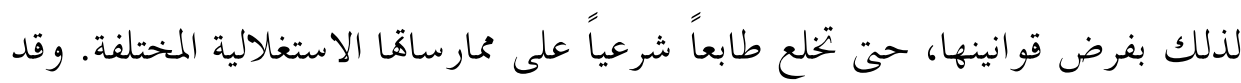
و جدد ذلك السعي وهذا الإدماج قابلية متمثلة في عنصر آخر، وهو ضعف بحتمعاتنــا و الخطاطها. ومن الوسائل الناجعة في ذلك، استبدال القـــوى الاســتعمارية قوانينـــها بأحكام الفقه، واستبدالها فلسفة المستعمرين وقيمهم بفلسفة الإسلام وقيمه الكبرى. إن التفاعل الإيجابي مقصد شرعي وأصل نقدي، ما أحو جنا إلى التشبع .مقتضــياته

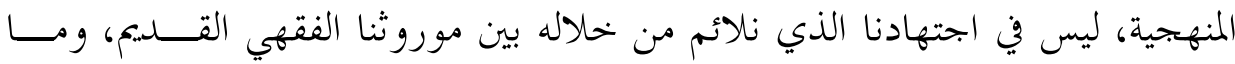
تجري عليه حياتنا من قوانين وضعية فحسب، وإنما أيضا في تحديدنا لخطابنا الفكـــري،

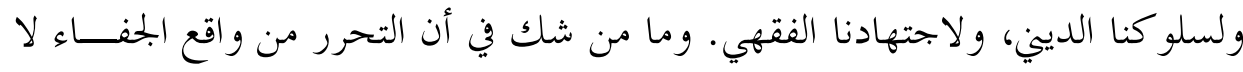
ينحصر في منطق الفعل السياسي، كما لا يتأتى .منطق الوعظ الإرشادي فحسب، بل لا بد أن يرافق ويسدد ويسند كل هذا وذاك اجتهادٌ فكري وفقهي، يســتلزم -أولاً وقبل كل شيء- الوعي بالتمايز الذي جاءت على هدي منه نصوصها وأحكامهــا. و الوعي بالتمايز في و اقعنا الراهن يستلزم الجمع المتآلف بين ما ينبغي أن بتــــي عليــــ حياة الناس، حتى تتسق مع الشريعة وأحكامها، وما تجري عليه حياهم المعاصرة، مــن الاحتكام إلى قو انين وضعية مستوردة. فهو اجتهاد يقوم على آليــات ثــلاث: آليـــة

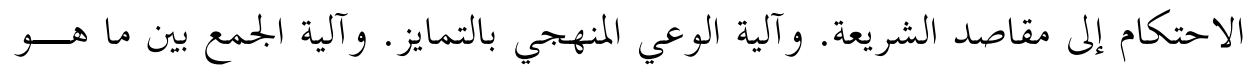
كائن وما ينبغي أن يكون. 
تبقى نتائج هذا الاجتهاد محل مساءلة مستمرة ومنظمة. لا يقوم هـا أهل النظر من

الشريعة وحدهم، بل هي من مسؤولية البحتمع كله؛ تتكاثف تياراته، وتتعاضد فئاتــه، و يتعاون ممثلوه على اختلاف تخصصاهم وتنوع كفاءاتم. و ذذلــك لا يتحقـــق إلا في إطارين: إطار مؤسسي ينظم هذه المسؤولية، وإطار معرفي يستوجب احتـــــرام مبــــأ

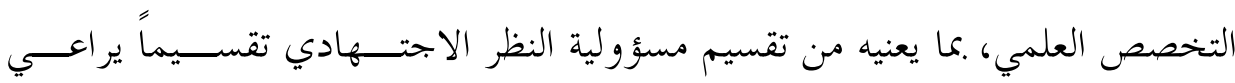
مستجدات الو اقع.

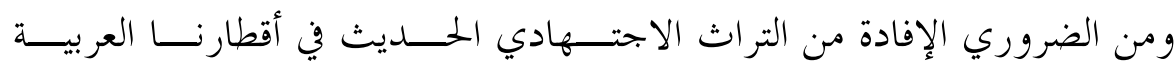
والإسالامية المختلفة، والحاجة ماسة إلى دراسات تطبيقية وتدقيقية، تنجز على مستوى كل قطر إسلامي على حدة. وبذلك نكون قد أسهمنا في و اجب تجنب إصدار كــثير

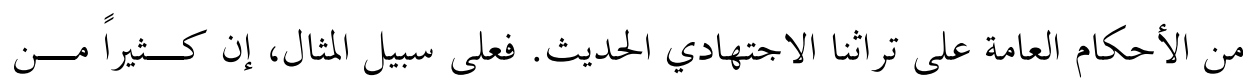

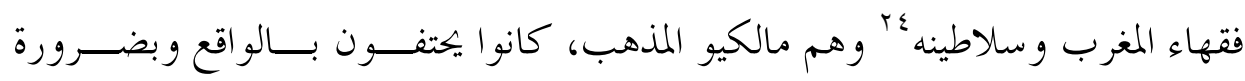

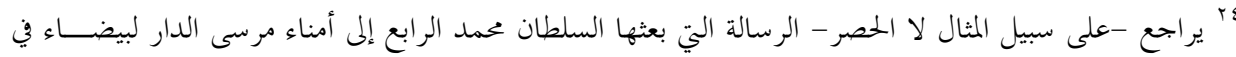

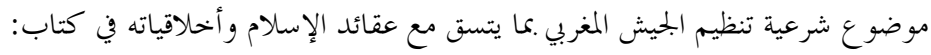

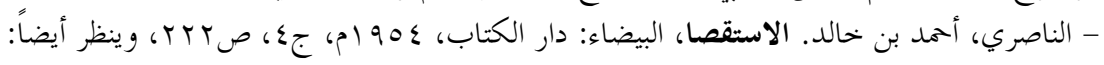

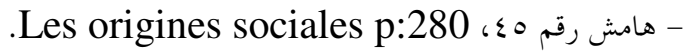

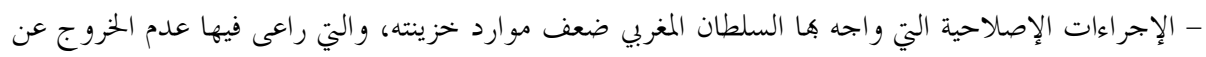

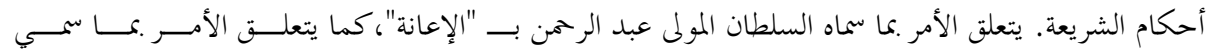

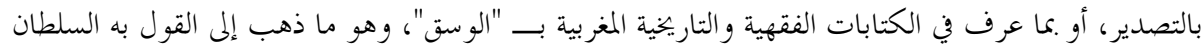

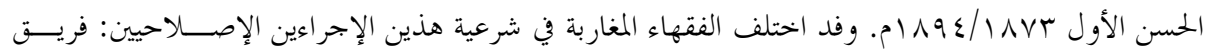

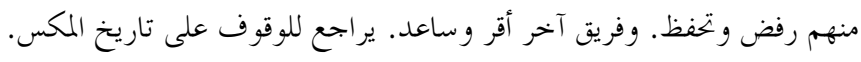

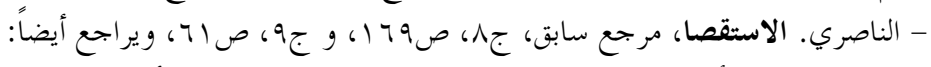

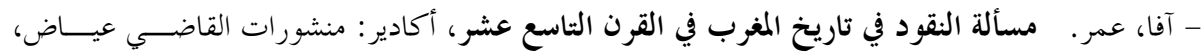
ص.

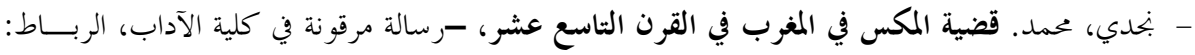

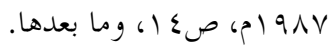
- الحسني، إسماعيل. مقاصد الشريعة والاجتهاد في المفرب الحديث. وهو قيد النشر 
التفاعل معه في جميع الأحوال، وينهلون دائماً من مقاصد الشريعة، قبل طبع الموافقات

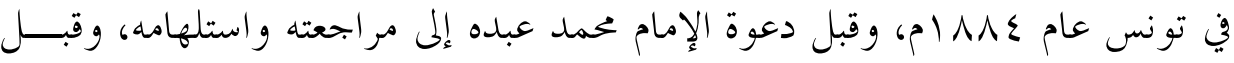
دعوة الإمام محمد الطاهر بن عاشور إلى بناء علم في مقاصد الشريعة. وقد قدّم هؤلاء السلاطين و الفقهاء -رحمهم الله- ثروة من الإجتهادات، في المواءمة بين ما ورثناه من أحكام فقهية، وما طرحته الضغوط الاستعمارية المتلونة من "إصلاحات قانونية مملاة"؛

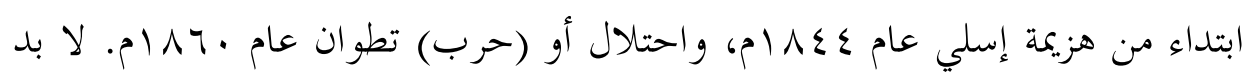
من الإفادة من هذا الاجتهاد الملائم الذي مسّ طوال القرن التاسع عشـــر، وإلى يـــوم الناس هذا، معظمَ تنظيماتنا العسكرية والمالية، وأوضاعنا الدينية والسياسية، وتعاملاتنا 